\title{
The chemistry of amine radical cations produced by visible light photoredox catalysis
}

\author{
Jie Hu, Jiang Wang, Theresa H. Nguyen and Nan Zheng ${ }^{*}$
}

\section{Review}

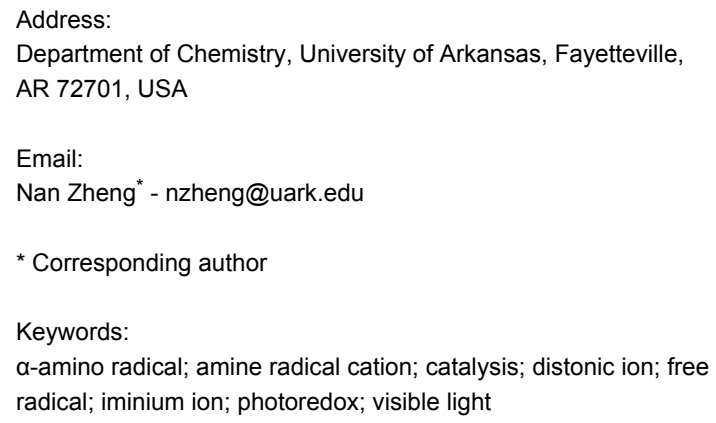

\begin{abstract}
Amine radical cations are highly useful reactive intermediates in amine synthesis. They have displayed several modes of reactivity leading to some highly sought-after synthetic intermediates including iminium ions, $\alpha$-amino radicals, and distonic ions. One appealing method to access amine radical cations is through one-electron oxidation of the corresponding amines under visible light photoredox conditions. This approach and subsequent chemistries are emerging as a powerful tool in amine synthesis. This article reviews synthetic applications of amine radical cations produced by visible light photocatalysis.
\end{abstract}

\section{Introduction}

Amine radical cations, which are an odd-electron species, are of great utility in amine syntheses [1-8]. They can be formed by loss of an electron from the corresponding amines. This oneelectron oxidation process has been realized by using electrochemistry [9-11], chemical oxidants [12-14], metal-catalyzed oxidation [15-18], UV light-mediated photochemistry [7,19-21], and visible light-mediated photochemistry [22,23]. Recently, the last approach has become a major research focus in organic chemistry. The enthusiasm surrounding this approach is partially driven not only by its green characteristics (i.e. using visible light), but also more importantly by its unique ability to achieve unconventional bond formation.
Like most organic compounds, amines do not absorb visible light efficiently, unless they have a chromophore (e.g., conjugated $\pi$-bond systems). Therefore, a photocatalyst is often required to initialize electron-transfer reactions with amines. Some of the frequently used photocatalysts include ruthenium [24-26] and iridium [27,28] polypyridyl complexes as well as organic dyes $[29,30]$ that are absorbed in the visible-light region. They all share one common characteristic: a facile intersystem crossing (ISC) that allows the conversion of the initially formed singlet photoexcited state to the relatively long-lived triplet photoexcited state. The triplet photoexcited state's long lifetime permits it to engage in single-electron transfer with 
organic molecules such as amines. The photoexcited state is both more oxidizing and more reducing than the ground state. It can be quenched reductively by accepting an electron from an electron donor or oxidatively by donating an electron to an electron acceptor. Amines are often used as an electron donor to reductively quench the photoexcited state while they are oxidized to amine radical cations. This single-electron transfer process was investigated intensively in the late 1970s and early 1980s because amines were used as a sacrificial electron donor in water splitting [31,32] and carbon dioxide reduction [33,34]. Since 2008, seminal works from MacMillan, Yoon, and Stephenson have reinvigorated the field of visible light photoredox catalysis [35-42]. The use of amines as both the electron donor and the substrate, rather than just the electron donor, has become a major approach to exploit synthetic utility of photogenically produced amine radical cations.

Reductive quenching of the photoexcited state of a photocatalyst (M) by amine $\mathbf{1}$ is governed by the reduction potentials of the photoexcited state and the amine (Scheme 1). The amine's reduction potential, which can be readily measured by cyclic voltammetry, should be less positive than that of the photoexcited M. The solvent also has a significant impact on the oxidation and the subsequent reactions $[43,44]$. A polar solvent is generally favored for electron-transfer reactions involving amine radical cations, but identification of the optimal solvent requires experimentation. Once formed, amine radical cation 2 has been shown to have four modes of reactivity. The first mode is the back electron transfer reaction, which involves amine radical cation 2 giving back one electron to $\mathrm{M}(n-1)$. This is a major side reaction competing against the other productive downstream reactions of $\mathbf{2}$. To circumvent this side reaction, two approaches or a combination thereof can be exploited $[45,46]$. One approach involves modifying the structure of the ligand on $\mathrm{M}$ to retard the back electron transfer. The other involves designing fast and/or irreversible downstream reactions of 2 . The second mode involves hydrogen atom abstraction from $\mathbf{2}$ to produce iminium ion $\mathbf{4}$, when a good hydrogen atom acceptor is present in the reaction. The use of amine radical cation 2 as the source of a hydrogen radical has been applied to a number of visible light-mediated reductions such as reductive dehalogenation [47-51], reductive radical cyclization [52-54], reduction of activated ketones [49], and reduction of aromatic azides [55]. The third mode involves deprotonation of amine radical cation 2 to form $\alpha$-amino radical 3 , which is converted to iminium ion $\mathbf{4}$ by another one-electron oxidation. The acidifying effect of one-electron oxidation on the $\alpha-\mathrm{C}-\mathrm{H}$ bond remains debatable [56-60]. The rate for deprotonation of amine radical cation 2 has been measured experimentally by several groups, and a broad range has been obtained [61,62]. $\alpha$-Amino radical 3 is strongly reducing [45,63], thus making the second one-electron oxidation facile. The last mode involves cleavage of a $\mathrm{C}-\mathrm{C}$ bond $\alpha$ to the nitrogen atom, yielding a neutral free radical 6 and iminium ion 5 . Iminium ion 4, an excellent electrophile, is amenable to interception by a variety of nucleophiles to directly install a new bond at the position $\alpha$ to the nitrogen atom. In contrast, $\alpha$-amino radical $\mathbf{3}$ is nucleophilic. It tends to add to electron-deficient alkenes to form a $\mathrm{C}-\mathrm{C}$ bond, also at the position $\alpha$ to the nitrogen atom.

This review will summarize the work to date on the use of amine radical cations generated under visible light photoredox conditions as a key intermediate to trigger downstream reactions. The work is grouped based on the key intermediates

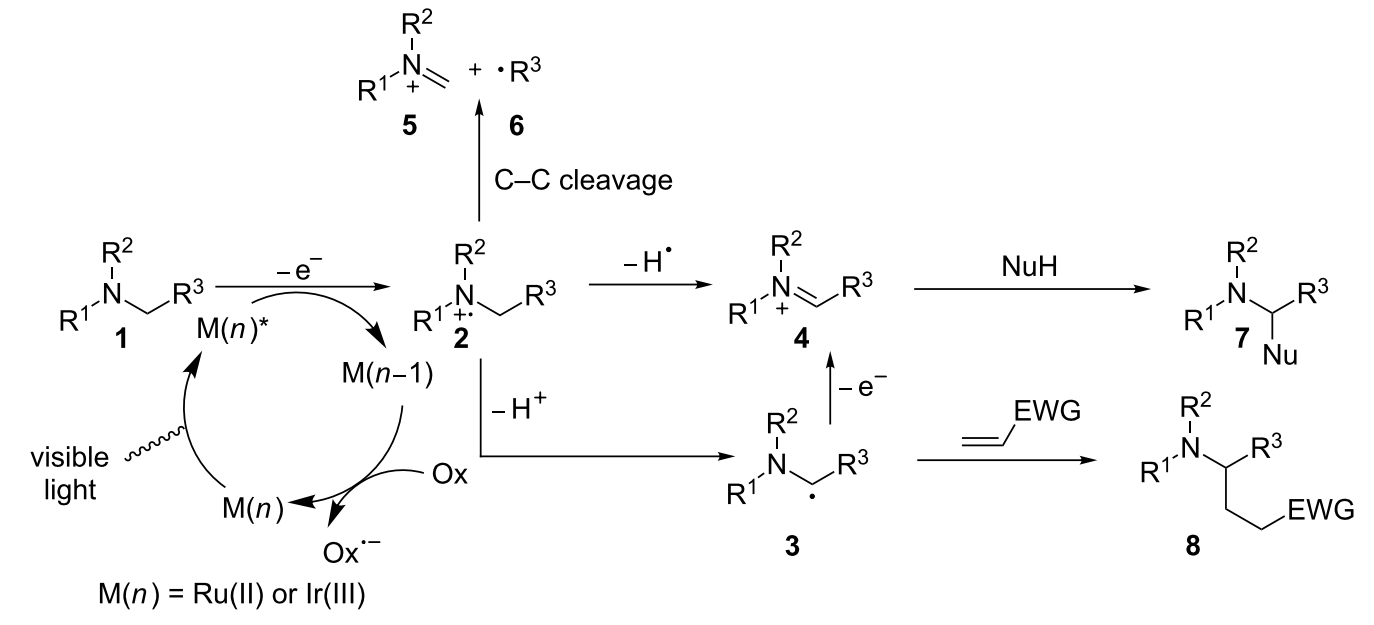


(iminium ions and $\alpha$-amino radicals) or processes (cleavage of $\mathrm{C}-\mathrm{C}$ and $\mathrm{N}-\mathrm{N}$ bonds) involved. The chemistries that have focused on the use of amines as a sacrificial electron donor only or as a hydrogen radical donor only will not be discussed in the review. These chemistries have been recently reviewed [22,23,35-42]. Photooxidation of amines to amine radical cations can also be achieved using UV light with a sensitizer. This approach and subsequent chemistries are also outside the scope of this review. Interested readers are referred to these reviews [7,19-21].

\section{Review \\ Iminium ions \\ Intercepted by carbon nucleophiles}

One of the major modes of reactivity for amine radical cations is their conversion to the powerful electrophilic iminium ions, which can be intercepted by a range of pronucleophiles to form a number of important bonds such as $\mathrm{C}-\mathrm{C}, \mathrm{C}-\mathrm{N}, \mathrm{C}-\mathrm{O}$, and $\mathrm{C}-\mathrm{P}$. The chemistry involving iminium ions has seen the most synthetic applications so far.

The Whitten group provided some early studies to establish the conversion of amine radical cations to iminium ions. In 1980, Giannotti and Whitten reported that irradiation of triethylamine with three ruthenium polypyridyl complexes using visible light in the presence of water yielded acetaldehyde, presumably formed by the hydrolysis of iminium ion 12 (Scheme 2) [46]. They proposed that reductive quenching of the photoexcited $\mathrm{Ru}(\mathrm{II})$ complex by triethylamine produced $\mathrm{Ru}(\mathrm{I})$ and amine radical cation 9 . Then amine radical cation 9 can either abstract a hydrogen atom from the solvent $\left(\mathrm{CH}_{3} \mathrm{CN}\right)$ to form carbon radical 10, or lose a proton to another molecule of triethylamine to form $\alpha$-amino radical 11. Carbon radical $\mathbf{1 0}$ is converted to $\alpha$-amino radical $\mathbf{1 1}$ by abstracting a hydrogen atom from a second molecule of triethylamine and $\mathrm{CH}_{3} \mathrm{CN}$ is ultimately regenerated. Finally, one electron oxidation of $\alpha$-amino radical $\mathbf{1 1}$ furnishes iminium ion $\mathbf{1 2}$ that is hydrolyzed to acetaldehyde. Although the authors were not able to detect amine radical cation $\mathbf{1 2}$ spectroscopically, they were able to use ESR (electron spin resonance) techniques to detect $\mathrm{Ru}(\mathrm{I})$ and $\alpha$-amino radical 11 with the aid of a spin trap, nitrosodurene.

In 2010, Stephenson and coworkers reported a visible lightmediated aza-Henry reaction that harnesses the synthetic potential of iminium ions. Using only $1 \mathrm{~mol} \%$ of $\left[\operatorname{Ir}(\mathrm{ppy})_{2}(\mathrm{dtbbpy})\right]\left(\mathrm{PF}_{6}\right)$ and visible light, a variety of $N$-aryltetrahydroisoquinolines were oxidatively coupled with nitroalkanes to provide the aza-Henry products in excellent yields (Scheme 3) [64]. They suggested that reductive quenching of the Ir(III) photoexcited state by $N$-aryltetrahydroisoquinolines $\mathbf{1 3}$ leads to the formation of amine radical cation 14 and the powerful reducing agent $\operatorname{Ir}(\mathrm{II})$ (Ir(III)/Ir(II), $-1.51 \mathrm{~V}$ vs SCE). The Ir(II) catalyst then reduces nitromethane or oxygen to a radical anion that may abstract a hydrogen atom from amine radical cation $\mathbf{1 4}$ to form the iminium ion 15. Interception of the iminium ion by the anion of nitromethane affords the aza-Henry product $\mathbf{1 6 .}$

Oxygen has been the most often used stoichiometric oxidant in the formation of iminium ions under photoredox conditions. However, this use has some limitations. The catalyst turnover mediated by $\mathrm{O}_{2}$ is often slow, resulting in long reaction time. $\mathrm{O}_{2}$ can also intercept $\alpha$-amino radicals, one of the key intermediates in the formation of iminium ions, to produce amides and thus compromise the formation of iminium ions $[65,66]$. The Stephenson group sought an alternative stoichiometric oxidant to overcome the limitations encountered by $\mathrm{O}_{2}$ (Scheme 4) [58]. $\mathrm{BrCCl}_{3}$ was identified as such an alternative and iminium ions were produced cleanly within 3 hours. A broad range of nucleophiles, including nitroalkanes, was shown to add to iminium ions. The authors proposed two possible mechanisms for the formation of iminium ions based on the two

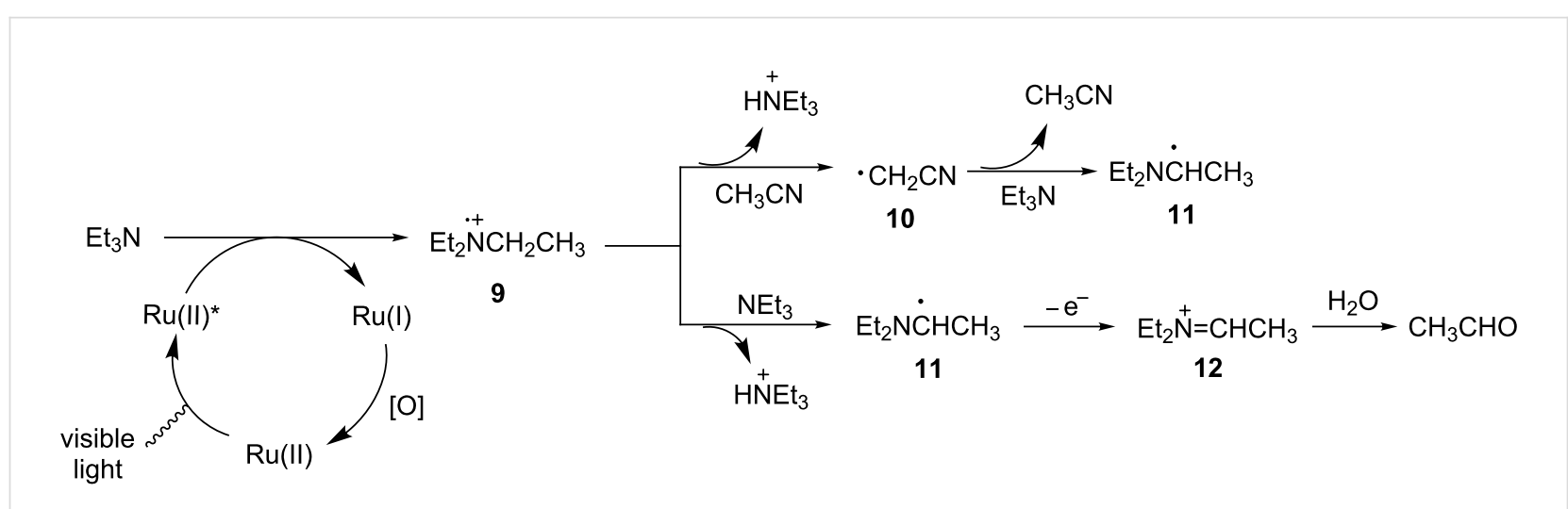



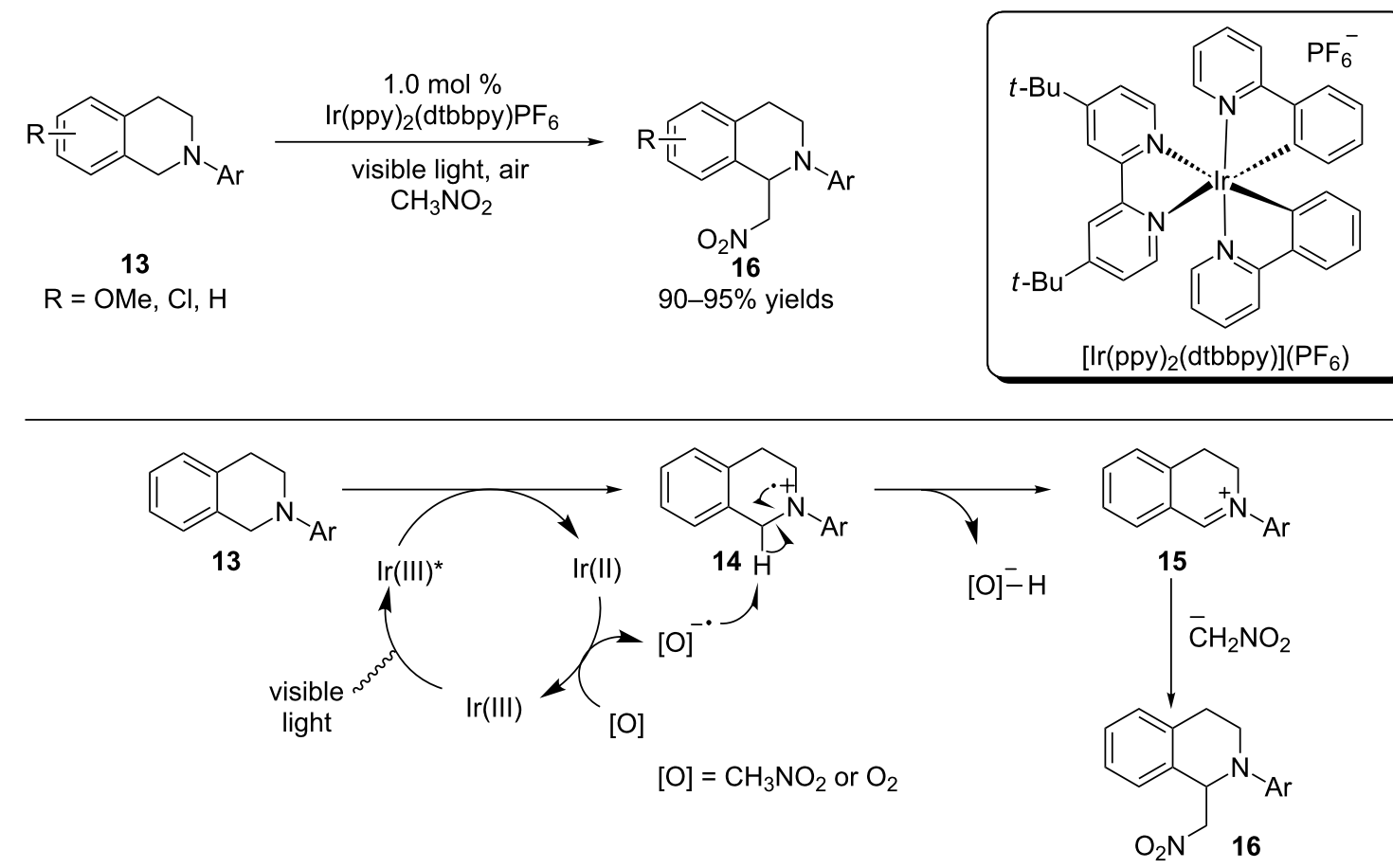

Scheme 3: Photoredox aza-Henry reaction.

divergent pathways for the conversion of amine radical cations to iminium ions. The first mechanism is based on the pathway involving abstraction of a hydrogen atom from amine radical cation 14. The hydrogen atom acceptor is a trichloromethyl radical, which is formed via one-electron reduction of $\mathrm{BrCCl}_{3}$ by $\mathrm{Ru}(\mathrm{I})$. The second is centered on the pathway involving deprotonation of amine radical cation $\mathbf{1 4}$ followed by one-electron oxidation. $\mathrm{BrCCl}_{3}$ is the one-electron oxidant via electron transfer or atom transfer. The trichloromethyl radical, which is generated by this oxidation, then abstracts a hydrogen atom of another molecule of $\mathrm{N}$-aryltetrahydroisoquinoline to produce the $\alpha$-amino radical 17 , which once again enters the radical chain process with $\mathrm{BrCCl}_{3}$.

König and coworkers showed that the same aza-Henry reaction can be catalyzed by the organic dye Eosin $\mathrm{Y}$ to afford the azaHenry product 18 (Scheme 5) [67]. In addition to nitroalkanes, dialkyl malonates and malononitrile can be used as pronucleophiles to provide $\beta$-diester amine 19 and $\alpha$-aminonitrile 20. The authors proposed a mechanism similar to that proposed by Stephenson and coworkers for the aza-Henry reaction catalyzed by the Ir complex (Scheme 3). The Tan group simultaneously reported that another organic dye, Rose Bengal (RB), can be used in place of Eosin $\mathrm{Y}$ to catalyze the aza-Henry reaction [68].
The Wu group concurrently developed the Eosin Y-catalyzed aza-Henry reaction as reported by König and also performed mechanistic studies on the reaction. Their proposed catalytic cycle for the reaction is detailed in Scheme 6 [69]. Wu and coworkers were able to obtain experimental evidence to lend support to some of the key steps in the catalytic cycle. An oxygen uptake experiment showed that 0.75 equiv of $\mathrm{O}_{2}$ was consumed for the complete conversion of $\mathrm{N}$-phenyltetrahydroisoquinoline 13. This data strongly supports the role of $\mathrm{O}_{2}$ as the stoichiometric oxidant. Flash photolysis studies established that reductive quenching of the triplet excited state of Eosin Y by $N$-phenyltetrahydroisoquinoline $\mathbf{1 3}$ produced the Eosin Y radical anion. An ESR study on the irradiated solution of DMPO (5,5-dimethyl-1-pyrroline- $N$-oxide), Eosin Y, and $\mathrm{N}$-phenyltetrahydroisoquinoline in air-saturated $\mathrm{CH}_{3} \mathrm{CN}$ detected the adduct of superoxide to DMPO. In contrast, an ESR study on the same solution but with DMPO being replaced by TEMP (2,3,6,6-tetramethylpiperidine) did not detect TEMPO, the oxidation product of TEMP by singlet oxygen. However, TEMPO was detected in the absence of $\mathrm{N}$-phenyltetrahydroisoquinoline. The results from these ESR studies are consistent with the notion that singlet oxygen is not formed in the presence of $N$-phenyltetrahydroisoquinoline and the Eosin $\mathrm{Y}$ radical anion reduces oxygen to superoxide. Finally, the yield of the product $\mathbf{1 8}$ increased when the reaction mixture was kept 


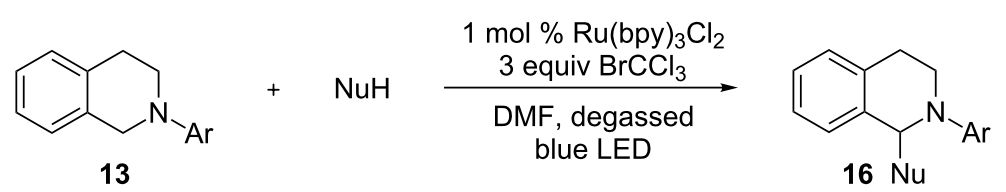

$16 \mathrm{Nu}$

$\mathrm{NuH}=\mathrm{sp}^{3}, \mathrm{sp}^{2}, \mathrm{sp}$ carbon nucleophile

mechanism 1<smiles>[Y]N1CCc2ccccc2C1</smiles>

13<smiles>CC1C(C)C1(C)Br</smiles>

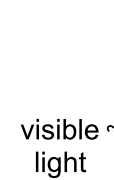
$\mathrm{Ru}(\mathrm{II})^{*}$<smiles>CC(C)C(C)C</smiles>
light

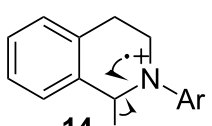
14 $\mathrm{Ru}(\mathrm{I})$

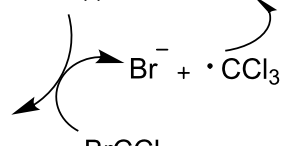<smiles>CC(C)C</smiles>

$\mathrm{R}-\mathrm{H}$<smiles>[Al][N+]1=Cc2ccccc2CC1</smiles>

15

mechanism 2

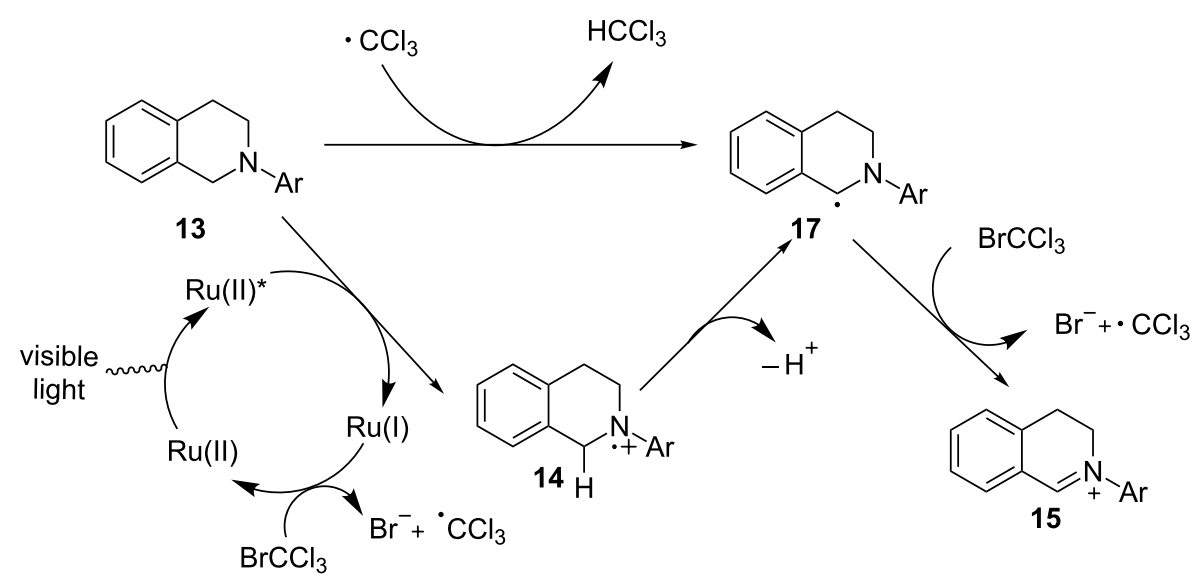

Scheme 4: Formation of iminium ions using $\mathrm{BrCCl}_{3}$ as stoichiometric oxidant.
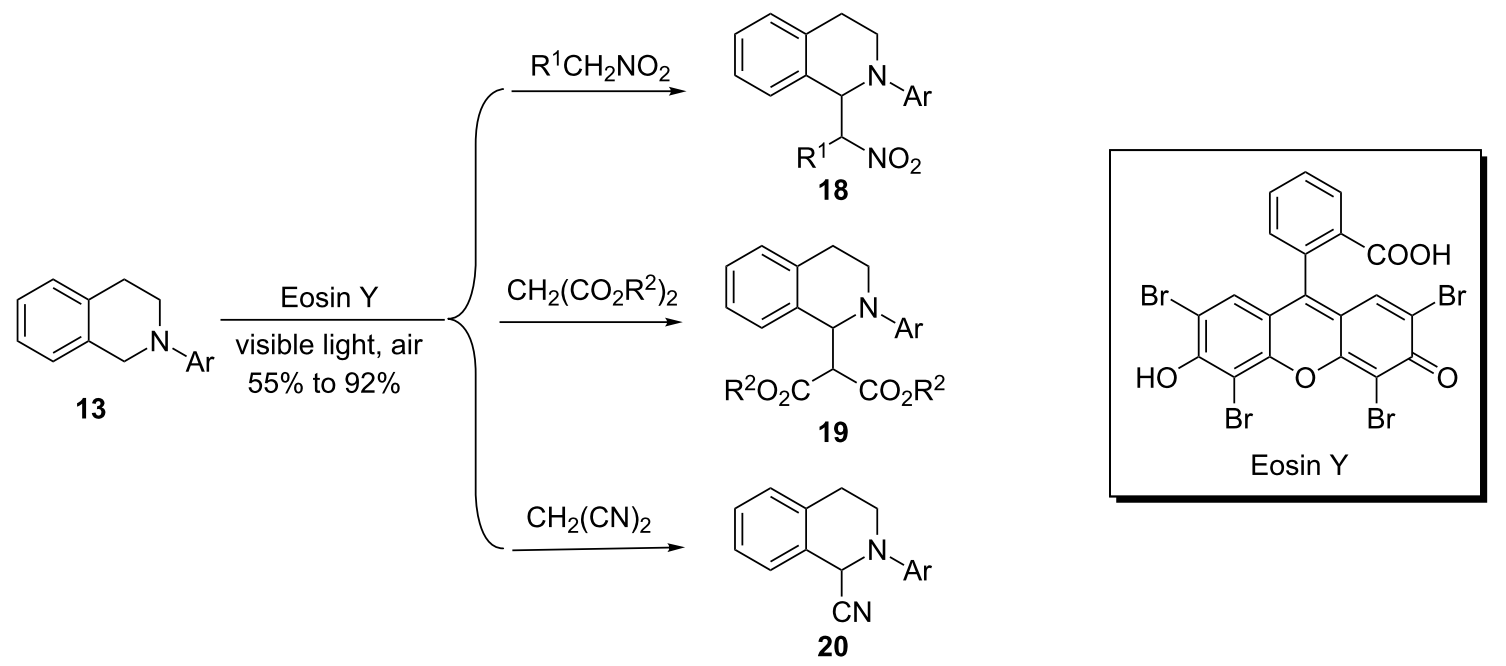

Scheme 5: Oxidative functionalization of $\mathrm{N}$-aryltetrahydroisoquinolines using Eosin $\mathrm{Y}$. 


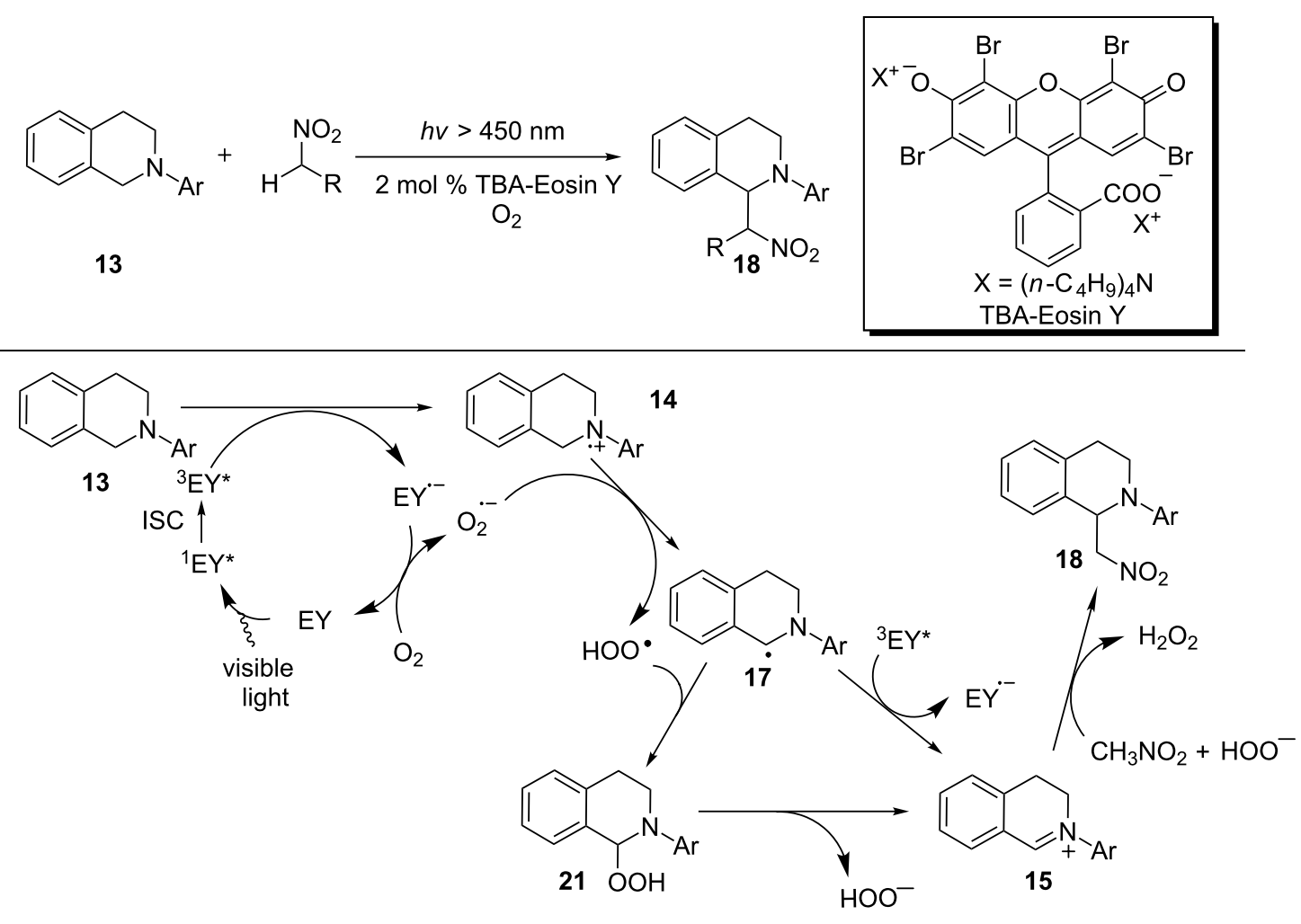

Scheme 6: Synthetic and mechanistic studies of Eosin Y-catalyzed aza-Henry reaction.

stirring in the dark after $4 \mathrm{~h}$ irradiation. This observation supports the formation of hydroperoxide intermediate $\mathbf{2 1}$.

Tan and coworkers employed a cocatalyst system composed of the organic dye Rose Bengal and graphite oxide (GO) for $\alpha$-cyanation of $N$-aryltetrahydroisoquinolines (Scheme 7) [70]. The use of GO as carbocatalyst, pioneered by the Bielawski group, has been shown to facilitate a variety of reactions including oxidation, reduction, dehydration, and $\mathrm{C}-\mathrm{C}$ bond formation [71-74]. GO was found to improve the yields of the $\alpha$-cyanation reaction, and this was the first example of using GO to promote visible light-mediated reactions. The synergistic effect between carbocatalysis and visible light-mediated photocatalysis has the potential to be further explored in other photocatalyzed reactions.

Since visible light photocatalysis is often orthogonal to or compatible with a number of common catalytic processes, merging it with another type of catalysis has become a recent development in the field of visible light photocatalysis. One

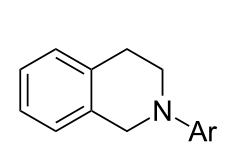

13

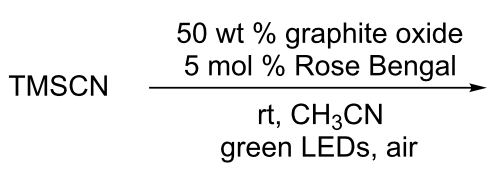

green LEDs, air<smiles>N#CC1c2ccccc2CCN1[Al]</smiles>

20

up to $99 \%$ yield<smiles>NC(=O)c1c(Cl)c(Cl)c(Cl)c(Cl)c1-c1c2cc(I)c(=O)c(I)c-2oc2c(I)c(O[N+]([O-])([O-])[O-])c(I)cc12</smiles> 
direct benefit of this dual catalysis approach is to allow expansion of the types of nucleophiles capable of adding to the iminium ions generated under photoredox conditions.

In 2011, Rueping and coworkers described a dual catalytic system combining photoredox and Lewis base catalysis for the functionalization of $\mathrm{C}-\mathrm{H}$ bonds $\alpha$ to the nitrogen atom of $\mathrm{N}$-aryltetrahydroisoquinoline $\mathbf{1 3}$ (Scheme 8) [65]. In the presence of a Lewis base, a ketone is converted to enamine nucleophile $\mathbf{2 8}$ in situ, which is then added to photogenically formed iminium ion $\mathbf{2 7}$ to yield the Mannich product 23. The Mannich reaction was sluggish without the Lewis base, and a side reaction, formation of the oxidized isoquinoline, became significant The choice of Lewis base was found to be also crucial for the outcome of the reaction and proline was more effective than pyrrolidine. Additionally, to maximize the yields, the optimal rates for the two catalytic processes need to be similar. Since formation of the iminium ions is much faster than the addition of the enamine nucleophiles, higher yields were realized with slower formation of the iminium ions. This was achieved by use of $\left[\mathrm{Ru}(\mathrm{bpy})_{3}\right]\left(\mathrm{PF}_{6}\right)_{2}$ in conjunction with a weak light source (5 W fluorescence bulb).

The Che group synthesized a photoactive gold(III) complex that was shown to catalyze $\alpha$-cyanation of $N$-aryltetrahydroisoquinolines [75]. Very recently, Zhu and coworkers used an analogous gold(III) complex to catalyze the reactions similar to those reported by the Rueping group (Scheme 9) [76]. A $5 \mathrm{~W}$ blue LED was used as the light source. One advantage of using the gold complex over $\left[\mathrm{Ru}(\mathrm{bpy})_{3}\right]\left(\mathrm{PF}_{6}\right)_{2}$ is that long-chain ali-

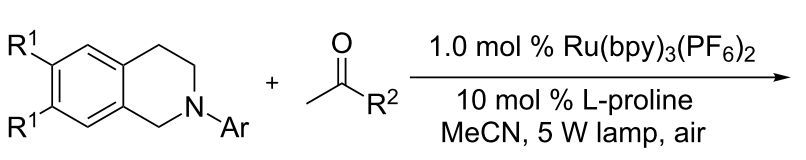

13<smiles>[R2]C(=O)CC1c2cc([R1])c([R])cc2CCN1[Al]</smiles>

$\mathrm{R}^{1}=\mathrm{H}, \mathrm{OMe} ; \mathrm{R}^{2}=\mathrm{Me}, \mathrm{Et}, \mathrm{CH}(\mathrm{OMe})_{2}$<smiles>CC(=O)CC1c2ccccc2CCN1c1ccccc1</smiles>

23

$95 \%$<smiles>COC(OC)C(=O)CC1c2ccccc2CCN1c1ccccc1</smiles>

24<smiles>COc1cc2c(cc1OC)C(CC(C)=O)N(c1ccccc1)CC2</smiles>

25<smiles>CC(=O)CC1c2ccccc2CCN1c1ccc(F)cc1</smiles>

26

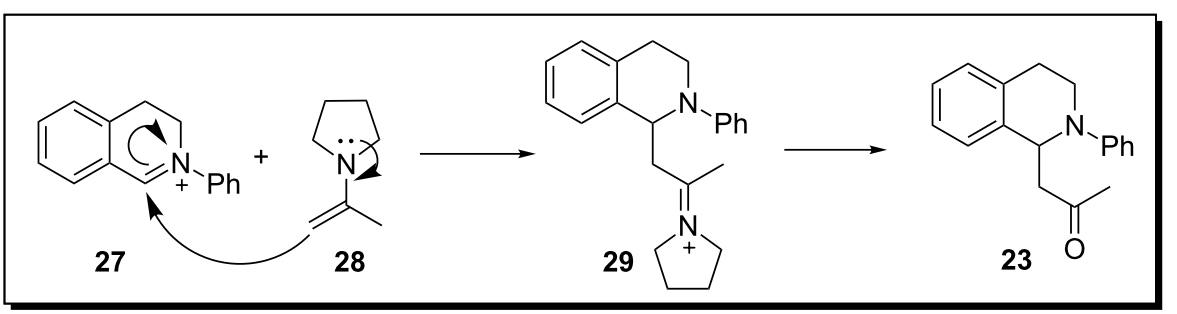

Scheme 8: Merging Ru-based photoredox catalysis and Lewis base catalysis for the Mannich reaction

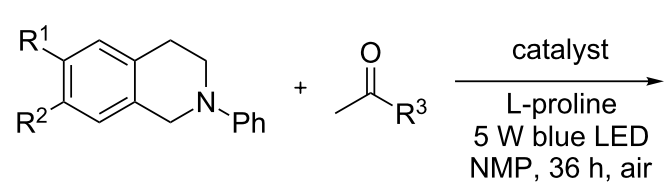

13

$\mathrm{R}^{1}, \mathrm{R}^{2}=\mathrm{H}, \mathrm{MeO} ; \mathrm{R}^{3}=$ alkyl<smiles>[R]c1cc2c(cc1[R])C(CC([R2])[R])N(c1ccccc1)CC2</smiles>

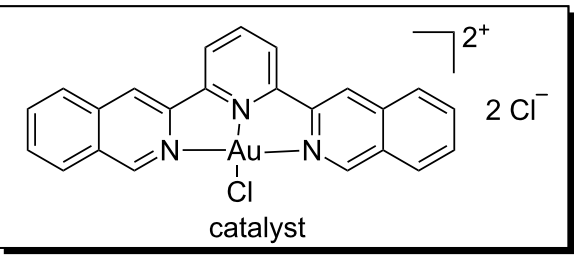

$66-96 \%$ yields 
phatic ketones work much better using the former catalyst. Other types of pronucleophiles such as malonates are also effective in the Mannich reaction.

The Rueping group extended the concept of dual catalysis by merging visible light photocatalysis with a metal-catalyzed process (Scheme 10) [77]. To make this approach work, several hurdles need to be addressed. First, a labile carbon-metal bond is desired in order to have an efficient turnover of the metal. Second, the metal complex needs to be compatible with the strongly reducing intermediates (e.g., superoxide) produced in the photocatalytic cycle. Third, the rates of the two catalytic cycles have to be comparable, as iminium ions are known to be converted to amides by superoxide $[65,66]$. Rueping and coworkers discovered that using a weak light source (5 W fluorescent bulb), copper acetylide $\mathbf{3 1}$, formed in situ by $(\mathrm{MeCN})_{4} \mathrm{CuPF}_{6}$, was added efficiently to the photogenicallyproduced iminium ion $27 \mathbf{a}$, thus achieving the formation of Csp ${ }^{3}-$ Csp bonds.

Rovis and coworkers recently developed another mode of dual catalysis involving visible light photocatalysis with chiral $\mathrm{N}$-heterocyclic carbene catalysis, which allows catalytic asymmetric $\alpha$-acylation of $N$-aryltetrahydroisoquinoline $\mathbf{1 3}$ with an aliphatic aldehyde (Scheme 11) [78]. In the presence of a $\mathrm{N}$-heterocyclic carbene (NHC), the aldehyde is converted to a chiral acyl anion or homoenolate equivalent $\mathbf{3 7}$, which is then added to the iminium ion $\mathbf{2 7}$ to form $\mathrm{Csp}^{3}-\mathrm{Csp}^{2}$ bonds asymmetrically. It is interesting to note that the use of $m$-dinitrobenzene $(m$-DNB) is critical to achieve the desirable conversion and yield of the expected product 32. $m$-DNB is proposed to act as an electron acceptor to promote an oxidative quenching cycle of $\mathrm{Ru}$ (bpy) $3^{2+*}$ to $\mathrm{Ru}(\mathrm{bpy}) 3^{3+} . \mathrm{N}$-aryltetrahydroisoquinoline $\mathbf{1 3}$ is then oxidized by $\mathrm{Ru}(\mathrm{bpy})_{3}{ }^{3+}$. This is in contrast to the majority of reported examples in which the conversion to the iminum ion such as $\mathbf{2 7}$ is realized in a reductive quenching cycle of $\mathrm{Ru}(\mathrm{bpy})_{3}{ }^{2+*}$ to $\mathrm{Ru}(\mathrm{bpy})_{3}{ }^{1+}$, where $\mathrm{N}$-aryltetrahydroisoquinoline $\mathbf{1 3}$ is oxidized by $\mathrm{Ru}(\mathrm{bpy})_{3}{ }^{2+*}$ instead.

Xiao [79] and Rueping [80] independently reported that when tetrahydroisoquinolines (e.g., 41 and $\mathbf{4 5}$ ) were substituted with a methylene group attached to one or two esters, the initially formed iminium ions were readily converted to azomethine ylides. They subsequently underwent 1,3-dipolar cycloaddition with a range of dipolarophiles to form fused pyrrolidines $\mathbf{4 3}$ and 47 (Scheme 12). Xiao also showed that the pyrrolidine ring of 43 could be further oxidized to a fused pyrrole 44 under the same photoredox conditions or by treatment with NBS. Both $\mathrm{Ru}(\mathrm{bpy})_{3} \mathrm{Cl}_{2}$ and $\mathrm{Ir}(\mathrm{bpy})(\mathrm{ppy})_{2}$ were found to be effective catalysts.

A plausible mechanism for the 1,3-dipolar cycloaddition is shown in Scheme 13. The reaction commences with oxidation of tetrahydroisoquinoline $\mathbf{4 1}$ to amine radical cation $\mathbf{4 8}$ by the photoexcited state of $\mathrm{Ru}^{2+}$. Subsequently, abstraction of a hydrogen atom $\alpha$ to the nitrogen atom of $\mathbf{4 8}$ yields iminium ion 49, which is then converted to azomethine ylide $\mathbf{5 0}$ by loss of a proton. 1,3-Dipolar cycloaddition of $\mathbf{5 0}$ with a dipolarophile $\mathbf{4 6}$ furnishes fused pyrrolidine $\mathbf{5 1}$ that is further oxidized to pyrrole 52.<smiles>[R]c1cc2c(cc1[R])CN([R])CC2</smiles>

13

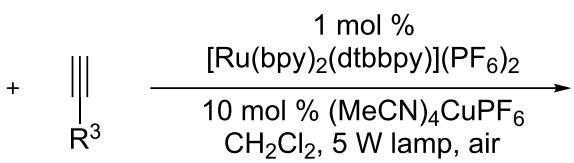

$\mathrm{CH}_{2} \mathrm{Cl}_{2}, 5 \mathrm{~W}$ lamp, air<smiles>[R]C#CC1c2cc([R1])c([R])cc2CCN1[R]</smiles>

30

$\mathrm{R}^{1}=\mathrm{H}, \mathrm{OMe} ; \mathrm{R}^{2}=\mathrm{Ar}$, alkyl; $\mathrm{R}^{3}=\mathrm{Ar}$, alkyl

$43-95 \%$ yields

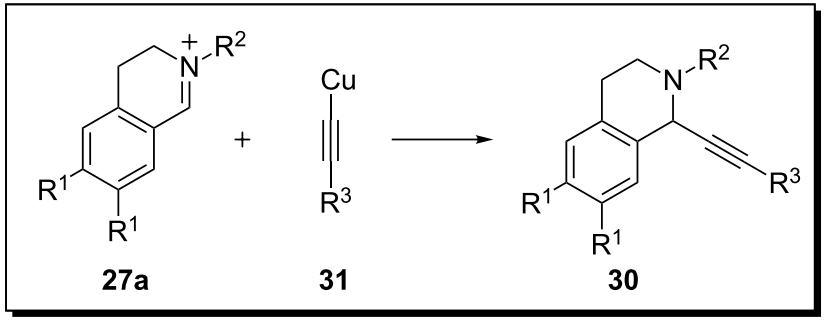


<smiles></smiles>

13
$5 \mathrm{~mol} \% \mathrm{NHC}$ $\underset{1.2 \text { equiv } m \text {-DNB }}{\stackrel{1 \mathrm{~mol} \% \mathrm{Ru}(\mathrm{bpy})_{3} \mathrm{Cl}_{2}}{\mathrm{CH}_{2} \mathrm{Cl}_{2} \text {, blue LEDs, air }}}$

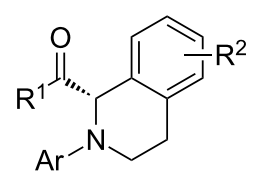

32

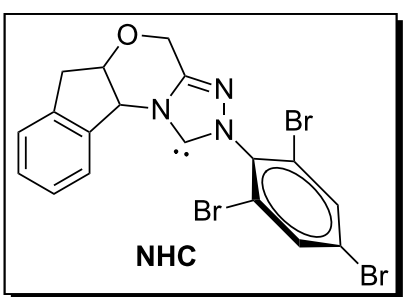<smiles>CCCC(=O)[C@@H]1c2ccccc2CCN1[N+](=O)[O-]</smiles>

36

$84 \%$ yield
35

$91 \%$ yield $92 \%$ ee

$91 \%$ yield

$72 \%$ yield

$67 \%$ ee<smiles>O=C(CCc1ccccc1)[C@H]1c2ccccc2CCN1c1ccccc1</smiles>

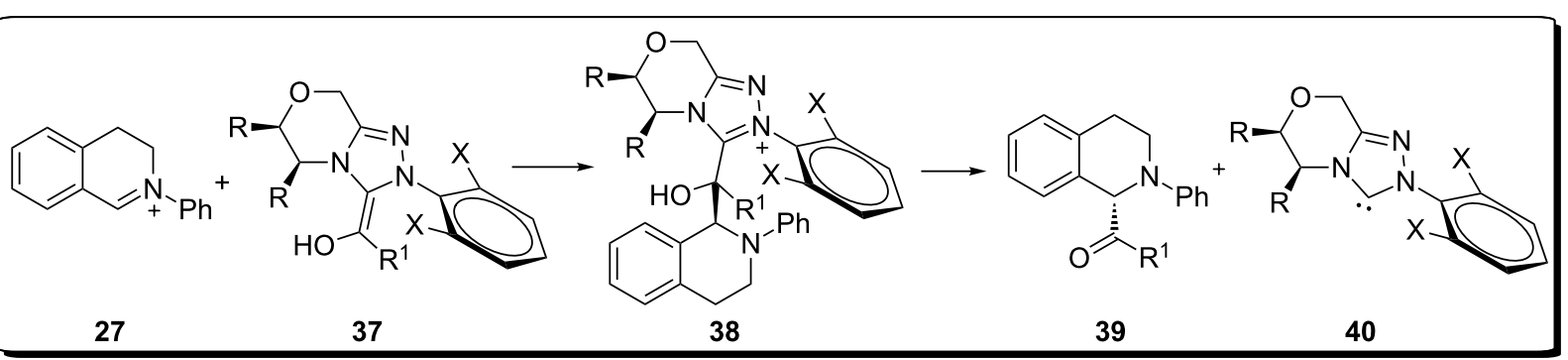

Scheme 11: Merging Ru-based photoredox catalysis and NHC catalysis.

\section{Xiao}<smiles>[R]C=Cc1ccc2cc1CN(CC(=O)OCC)CC2</smiles>
41

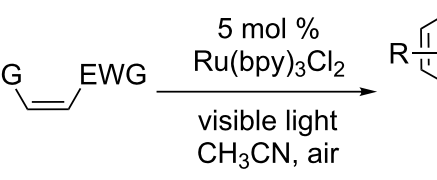

42<smiles>CCOC(=O)C1C(C#N)C(C)C2c3ccccc3CCN12</smiles>

43<smiles>CCOC(=O)c1c(C#N)c(C(C)(C)C)c2n1CCc1cc[R]cc1-2</smiles>

44

\section{Rueping}<smiles>[R1]C=CC1=CC=C2CN(C(C(=O)O[R2])C(=O)O[R12])CC12</smiles>

45<smiles></smiles>

46

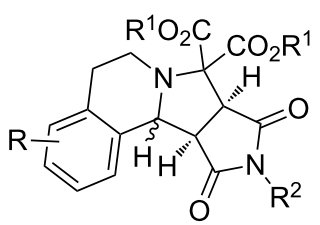

47

$56-67 \%$

Scheme 12: 1,3-Dipolar cycloaddition of photogenically formed azomethine ylides.

The Zhu group discovered that the use of $\alpha$-ketoester $\mathbf{5 3}$ as a pronucleophile to intercept the iminium ion of $\mathbf{1 3}$ triggered a new cascade reaction en route to fused isoxazolidine $\mathbf{5 4}$ in excellent diastereoselectivity ( $>20: 1$, Scheme 14) [81]. Alcohols were found to be the solvent of choice for this reaction.
Among the three alcohols screened, $\mathrm{PrOH}$ was more effective than $\mathrm{MeOH}$ or $\mathrm{EtOH}$, resulting in a shorter reaction time. The addition of a catalytic amount of TfOH had marginally beneficial effects on the reaction time and yields. Interestingly, depending on the electronic character of the $N$-aryl group, 


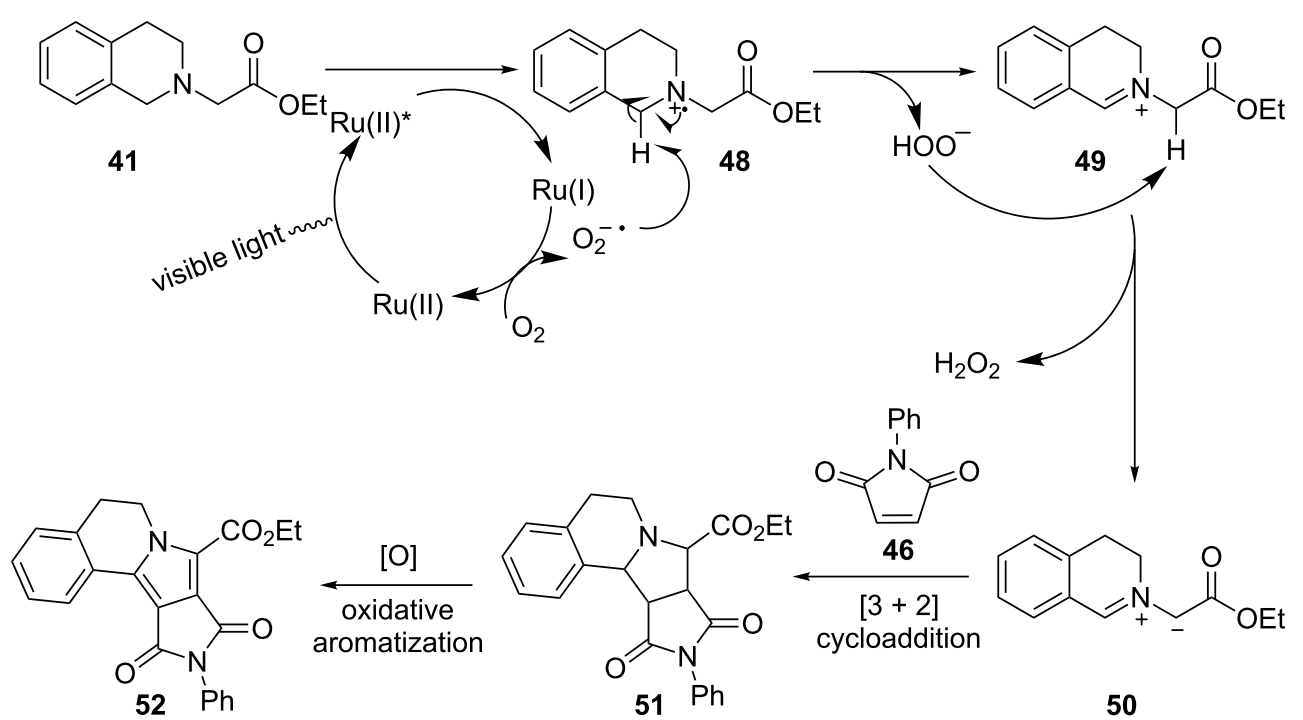

Scheme 13: Plausible mechanism for photoredox 1,3-dipolar cycloaddition.

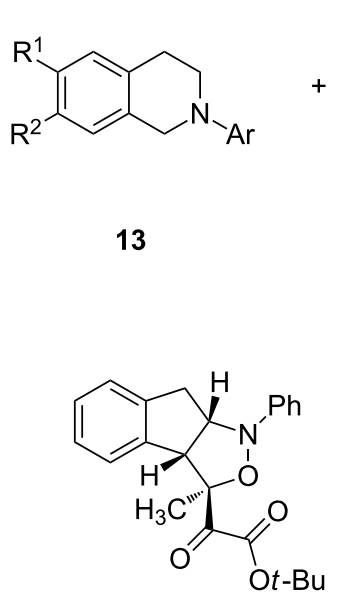

55

$63 \%,>20: 1$ d.r.<smiles>[R]CC(=O)C(=O)O[Na]</smiles>

53<smiles>CC(C)OC(=O)C(=O)[C@@]1(C)ON(c2ccccc2)[C@H]2CC3COCC3[C@H]21</smiles>

56

$<10 \%$
$\mathrm{Ru}(\mathrm{bpy})_{3} \mathrm{Cl}_{2}$ or $\left[\operatorname{lr}(\mathrm{ppy})_{2}(\mathrm{dtbbpy})\right]\left(\mathrm{BF}_{4}\right)$

$\mathrm{TfOH}$, visible light iPrOH, air

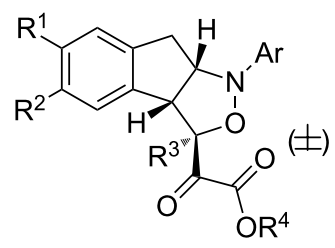

54

d.r. $>20: 1 ; 28-69 \%$ yields<smiles>CCCCOC(=O)C(=O)[C@]1(CC)ON(c2ccccc2)[C@H]2Cc3ccccc3C21</smiles>

57<smiles>C=CCC[C@]1(C(=O)C(=O)OCC)C(=O)ON2c3ccccc3C[C@H]21</smiles>

58

Scheme 14: Photoredox-catalyzed cascade reaction for the synthesis of fused isoxazolidines.

$\left[\operatorname{Ir}(\mathrm{ppy})_{2}(\mathrm{dtbbpy})\right]\left(\mathrm{BF}_{4}\right)$ or $\mathrm{Ru}(\mathrm{bpy})_{3} \mathrm{Cl}_{2}$ was used to obtain optimal yields. The former catalyst worked better with electronpoor $N$-aryl groups while the latter was more effective for electron-rich $\mathrm{N}$-aryl groups.

The authors proposed a possible mechanism that starts with reductive quenching of the photoexcited state of $\mathrm{Ru}(\mathrm{II})$ or $\mathrm{Ir}(\mathrm{III})$ by $N$-phenyltetrahydroisoquinoline 13 (Scheme 15). The initially formed amine radical cation $\mathbf{1 4}$ is converted to iminium ion 15 by abstraction of a hydrogen atom directly. The addition of the enol form of $\alpha$-ketoester $\mathbf{5 9}$ to $\mathbf{1 5}$ furnishes the Mannich adduct 60. A retro-aza-Michael reaction via enol $\mathbf{6 1}$ allows cleavage of the $\mathrm{C}-\mathrm{N}$ bond to yield secondary aniline $\mathbf{6 2}$. Aniline 62 is first oxidized to imine $\mathbf{6 3}$, which is further oxidized to nitrone 64. Finally, an intramolecular 1,3-dipolar cycloaddition of 64 furnishes isoxazolidine 55.

Tetrahydroisoquinolines are arguably the most exploited amines in visible light photoredox catalysis. However, efforts towards expanding the scope of amines have been recently reported. Li [82] and Rueping [83] independently reported that $N$-arylglycine derivatives $\mathbf{6 5}$ are viable substrates (Scheme 16). They 


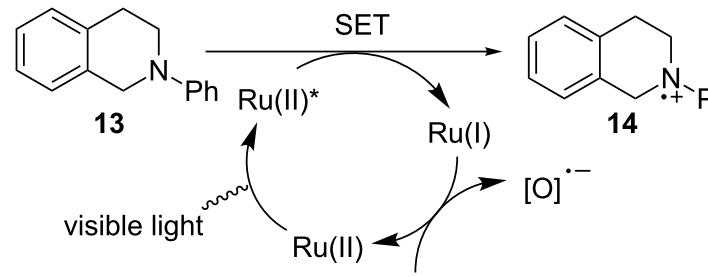

[O]

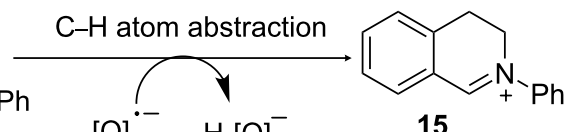

$\left.{ }^{0}\right]^{--} \mathrm{H}-[\mathrm{O}]^{-}$ 15

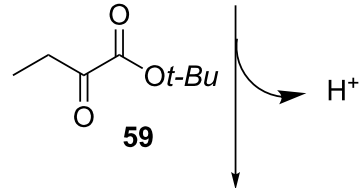<smiles>C/C=C\CCc1ccccc1/C=C(\C)C(=O)C(=O)OCC(C)(C)C</smiles>

63<smiles>C/C(=C\c1ccccc1CCNc1ccccc1)C(=O)C(=O)OC(C)(C)C</smiles>

62<smiles>CC(C(=O)OC(C)(C)C)=C1c2ccccc2CCN1C(O)C(O)(c1ccccc1)c1ccccc1</smiles>

61<smiles>C#CCOC(=O)C(=O)C(C)C1c2ccccc2CCN1c1ccccc1</smiles>

60<smiles>CC(C)(C)COC(=O)OC(=O)C(=Cc1ccccc1CC=[N+]([O-])c1ccccc1)C(=O)C(=O)OC(C)(C)C</smiles>

64<smiles>CCCCOC(=O)C(=O)[C@H]1ON(c2ccccc2)[C@H]2Cc3ccccc3[C@H]12</smiles>

55

Scheme 15: Plausible mechanism for the photoredox-catalyzed cascade reaction.

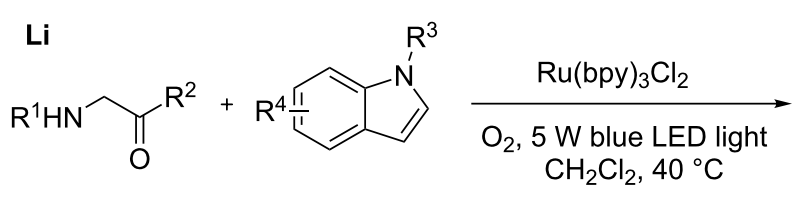

65<smiles>[R1]NC(C([R])=O)c1cn([R])c2cc[R]#cc12</smiles>

67 (43-75\% yields)

$R^{1}=A r ; R^{2}=A r, O E t ; R^{3}=H, M e, B n, A c ;$

$\mathrm{R}^{4}=\mathrm{H}$, alkyl, alkene, $\mathrm{Cl}, \mathrm{Br}$

\section{Rueping}

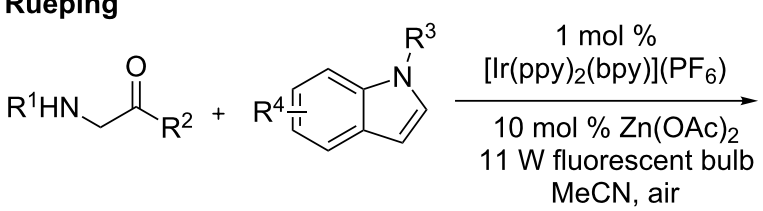<smiles>[R1]NC(C([R])=O)c1cn([R])c2c1C=C[R4]C=C2</smiles>

67 (42-83\% yields)

$\mathrm{R}^{1}=\mathrm{Ar} ; \mathrm{R}^{2}=\mathrm{OR}, \mathrm{NHR} ; \mathrm{R}^{3}=\mathrm{H}, \mathrm{Me}, \mathrm{TBS}, \mathrm{Bn}, \mathrm{Ac} ;$

$\mathrm{R}^{4}=\mathrm{H}, \mathrm{Ph}, \mathrm{Me}, \mathrm{OMe}, \mathrm{CO}_{2} \mathrm{Me}, \mathrm{CN}, \mathrm{Br}, \mathrm{I}, \mathrm{F}$.

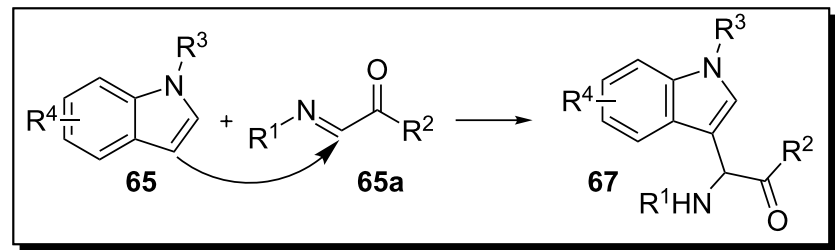


are presumably converted to imines $\mathbf{6 5 a}$ that are intercepted by indoles to give the Mannich-like adducts 67. The conditions used by $\mathrm{Li}$ were $10 \mathrm{~mol} \% \mathrm{Ru}(\text { bpy })_{3} \mathrm{Cl}_{2}$ and $1 \mathrm{~atm} \mathrm{O}_{2}$ at $40{ }^{\circ} \mathrm{C}$ with a $5 \mathrm{~W}$ blue LED as the light source. $\mathrm{N}$-arylglycine derivatives 65, including esters and ketones, were successfully converted to the products 67. Rueping used $\operatorname{Ir}(\mathrm{ppy})_{2}(\mathrm{bpy}) \mathrm{PF}_{6}$ as the photocatalyst, air, and an $11 \mathrm{~W}$ fluorescent bulb as the light source. Additionally, $\mathrm{Zn}(\mathrm{OAc})_{2}$ was employed as a Lewis acid cocatalyst. It was postulated that $\mathrm{Zn}(\mathrm{OAc})_{2}$ facilitates the conversion of the initially formed amine radical cation to the imine 65a and subsequently activates the imine for nucelophilic attack. $\mathrm{N}$-arylglycine esters and $\mathrm{N}$-arylglycine derived dipeptides worked quite well under these conditions. However, the ketones failed to provide the desired products.

Amides 68 are generally much more difficult to be oxidized than amines. Their reduction potentials range from $1.2-1.5 \mathrm{~V}$ (vs SCE) for tertiary amides to $2.0 \mathrm{~V}$ (vs SCE) for primary amides [84] which makes them less susceptible to oxidation by the photoexcited state of $\mathrm{Ru}(\mathrm{II})$ or $\operatorname{Ir}(\mathrm{III})$ complexes $\left(\mathrm{Ru}(\mathrm{bpy})_{3}{ }^{2+*} / \mathrm{Ru}^{1+}: 0.77 \mathrm{~V}\right.$ vs SCE; $\operatorname{Ir}(\mathrm{ppy})_{2}(\mathrm{dtbbpy})^{+* /}$ $\operatorname{Ir}(\mathrm{ppy})_{2}$ (dtbbpy), $0.66 \mathrm{~V}$ vs SCE) [35]. Stephenson and coworkers devised a strategy by reversing the order of oxidation and $\mathrm{C}-\mathrm{H}$ abstraction to overcome this issue (Scheme 17) [85]. The first intermediate formed is a strongly reducing $\alpha$-amino radical 68a that is oxidizable by the photoexcited state of $\mathrm{Ru}(\mathrm{II})$ or $\mathrm{Ir}(\mathrm{III})$. The $\alpha$-amino radical 68a is formed via $\mathrm{C}-\mathrm{H}$ abstraction by the sulfate radical anion $\left(\mathrm{SO}_{4}^{-\cdot}\right)$, which is gener- ated by exposure of $\mathrm{Ru}^{2+*}$ to persulfate $\left(\mathrm{S}_{2} \mathrm{O}_{8}{ }^{2-}\right)$, an oxidative quencher. Electron-rich arenes and indoles are then added to the $\mathrm{N}$-acyliminium ions $\mathbf{6 8 b}$ to provide the amidoalkylation products 69. Alternatively, the use of only persulfate at $55^{\circ} \mathrm{C}$ afforded the same products. However, higher yields and better selectivities were generally observed with the photocatalytic process.

\section{Intercepted by nitrogen, oxygen, or phosphorus nucleophiles}

In addition to carbon nucleophiles, heteronucleophiles including nitrogen, oxygen, and phosphorus are susceptible to interception of the photogenically formed iminium ions. The Xiao group developed a highly diastereroselective route to substituted tetrahydroimidazoles $\mathbf{7 2}$ based on intramolecular interception of the iminium ions by a tethered sulfonamide (71, Scheme 18) [86]. $\mathrm{Ru}(\mathrm{bpy}){ }_{3} \mathrm{Cl}_{2}$ was employed as the photocatalyst with oxygen as the stoichiometric oxidant. The use of a base in an alcohol solvent, such as $\mathrm{MeOH}$, was also the key to the success of this reaction. The diastereoselectivities were greatly improved by prolonging the reaction time, which would allow for epimerization leading to the thermodynamically more stable products. The starting materials, 1,2-diamines 70, were readily prepared from natural amino acids in enantiomerically pure form.

Xiao and coworkers then applied the same strategy to prepare two other types of heterocycles, isoquino[2,1-a][3,1]oxazine<smiles>[R]CN([R16])C([R])=O</smiles>

$\mathrm{NuH}$ :<smiles>COc1cc(OC)cc(OC)c1</smiles><smiles>COc1ccc(C)c(OC)c1</smiles><smiles>COc1cccc(OC)c1</smiles><smiles>[R]n1ccc2ccccc21</smiles>

$\mathrm{R}=\mathrm{CH}_{3}, \mathrm{Ph}, \mathrm{Bn}, \mathrm{H}$

alkylamides:<smiles>CN(C)C=O</smiles><smiles>CC(=O)N(C)C</smiles><smiles>CN1CCCC1=O</smiles><smiles>[R1]CN([R])C(=O)C([R5])[R15]</smiles><smiles>[R]CN([R2])C([R])=O</smiles><smiles>[R]C=[N+]([R2])C([R])=O</smiles><smiles>[R]C(=O)N([R])C([R])[N]</smiles> 


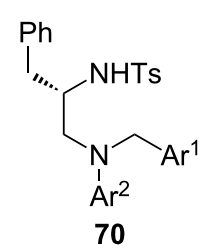

70

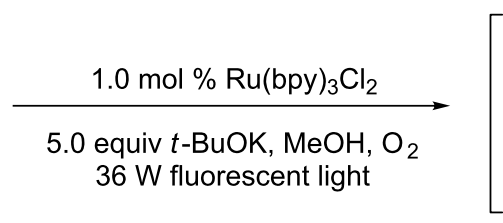

$36 \mathrm{~W}$ fluorescent light
3 -BuOK,

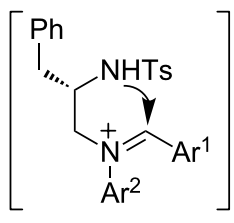

71

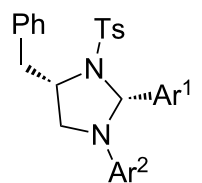

72

$90-93 \%$ yields, d.r. $>8: 1$

Scheme 18: Intramolecular interception of iminium ions by sulfonamides

and isoquino[2,1-a]pyrimidine (75, Scheme 19) [87]. The use of $\left[\operatorname{Ir}(\mathrm{ppy})_{2}(\mathrm{dtbbpy})\right]\left(\mathrm{PF}_{6}\right)$ with air as the external oxidant was found to be optimal for catalyzing the reaction. Later, the Marvin group reported an identical synthesis of isoquino[2,1a] $\left[3,1\right.$ ] oxazine using $\mathrm{Ru}(\mathrm{bpy})_{3} \mathrm{Cl}_{2}$ instead [88]. The tethered nucleophiles, primary alcohols or sulfonamides, are part of the $\mathrm{N}$-aryl group of tetrahydroisoquinolines $\mathbf{7 3}$. Similar to the synthesis of tetrahydroimidazoles $\mathbf{7 2}, \mathrm{MeOH}$ was the optimal solvent. No external base was needed when the alcohol was the nucleophile. However, if the sulfonamide was the nucleophile, an external base such as $t$-BuOK was required presumably to increase the nucleophilicity of the sulfonamide.

The Rueping group trapped the iminium ions using phosphites 76 to produce $\alpha$-amino phosphonates 78 (Scheme 20) [89]. $\left[\operatorname{Ir}(\mathrm{ppy})_{2}(\mathrm{bpy})\right]\left(\mathrm{PF}_{6}\right)$ was found to be the most effective cata- lyst. Interestingly, a biphasic mixture of toluene and water turned out to be the optimal solvent. The often-observed byproducts, amides derived from over-oxidation of the iminium ions, were suppressed $[65,66]$. The reactions were also sensitive to the steric and electronic nature of phosphites. Phosphites are quite acidic; their $\mathrm{p} K_{\mathrm{a}} \mathrm{s}$ are similar to alcohols. Less sterically hindered phosphites reacted faster as did more acidic phosphites (e.g., diphenylphosphite).

The König group applied the organic dye Eosin Y as the photocatalyst to catalyze the same reactions (Scheme 21) [67]. The reactions were irradiated in DMF with green LED light, which overlapped with the $\lambda_{\max }$ of Eosin Y. The yields are comparable for the two catalyst systems, but the reactions catalyzed by Eosin $\mathrm{Y}$ are much faster (note: the conclusion is based on $2 \mathrm{~mol} \%$ Eosin Y vs $\left.1 \mathrm{~mol} \%\left[\operatorname{Ir}(\mathrm{ppy})_{2}(\mathrm{bpy})\right]\left(\mathrm{PF}_{6}\right)\right)$.<smiles>[R]Cc1cc[R]#cc1N1CCc2cc[R1]cc2C1</smiles>

73

\section{$0.5 \mathrm{~mol} \%$ $\left[\operatorname{lr}(\text { ppy })_{2}(\mathrm{dtbbpy})\right]\left(\mathrm{PF}_{6}\right)$ \\ $\mathrm{MeOH} / \mathrm{air}$ \\ 36 W fluorescent light}

$X=\mathrm{O}, \mathrm{NTs}$

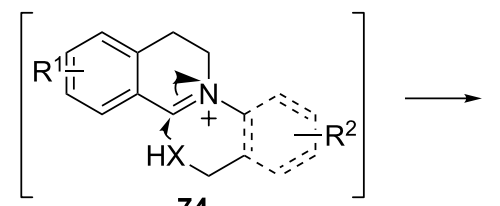

74

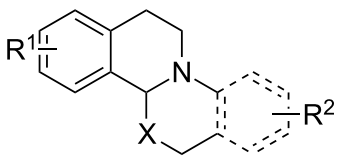

75

$26-86 \%$ yields

Scheme 19: Intramolecular interception of iminium ions by alcohols and sulfonamides.

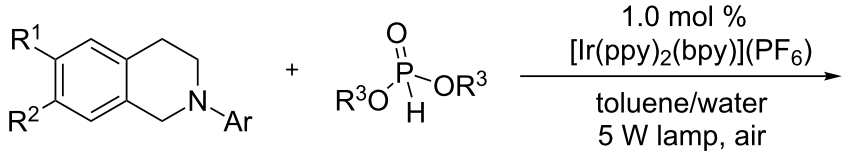

76<smiles>[R]c1cc2c(cc1[R])[C@@]1(CC)CCC2=[N+](CC)CC1</smiles><smiles>[R7]c1cc2c(cc1[R])C(P([R20])[O-])N([Al])CC2</smiles>

78

$55-90 \%$ yields 


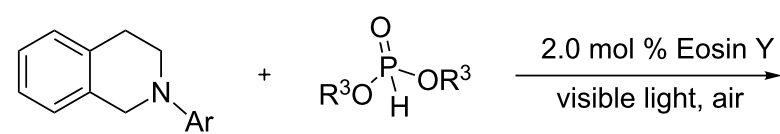

76

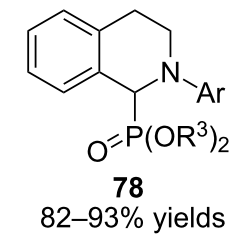

$82-93 \%$ yields

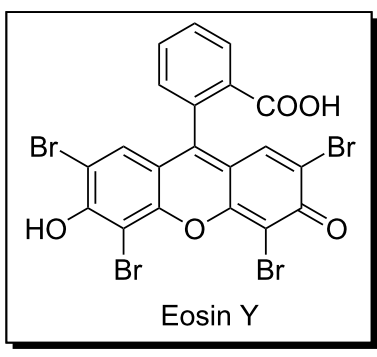

Scheme 21: Photoredox-catalyzed oxidative phosphonylation by Eosin $Y$.

\section{a-Amino radicals}

$\alpha$-Amino radicals are another class of downstream intermediates produced from amine radical cations. They are also the key intermediate in one of two potential pathways for the conversion of amine radical cations to iminium ions (Scheme 1). In contrast to the electrophilic nature of iminum ions, $\alpha$-amino radicals are nulceophilic. They tend to add to Michael acceptors in a 1,4 fashion. Since the addition is overall redox neutral, no external oxidant is required. Most of these addition reactions are conducted under degassing conditions. This is in contrast to the chemistries involving iminium ions, which are often performed with exposure to air or oxygen. The reactivity umpolung at the carbon $\alpha$ to the nitrogen atom has expanded the repertoire of amine radical cations' modes of reactivity. Compared to iminium ions, $\alpha$-amino radicals have been much less exploited as synthetic intermediates. Their synthetic applications remain limited.

Pandey and Reiser revealed that $\alpha$-amino radicals derived from $\mathrm{N}$-aryltetrahydroisoquinolines were added intermolecularly to Michael acceptors (Scheme 22) [66]. A blue LED was used as the light source. Both $\mathrm{Ru}(\mathrm{bpy})_{3} \mathrm{Cl}_{2}$ and $\left[\operatorname{Ir}(\mathrm{ppy})_{2}(\mathrm{dtbbpy})\right]\left(\mathrm{PF}_{6}\right)$ were found to catalyze the reactions. However, in some of the examples, the Ir catalyst gave better yields. Mechanistically, reductive quenching of the photoexcited $\mathrm{Ru}$ (II) or Ir(III) complex by $N$-aryltetrahydroisoquinolineamine yields amine radical cation 14, which is converted to $\alpha$-amino radical 17 . Conjugated addition of $\mathbf{1 7}$ to methyl vinyl ketone produces radical $\mathbf{7 9}$, which is reduced by the $\mathrm{Ru}(\mathrm{I})$ or $\operatorname{Ir}(\mathrm{II})$ complex with concomitant regeneration of the $\mathrm{Ru}(\mathrm{II})$ or $\operatorname{Ir}(\mathrm{III})$ complex. Protonation of the resulting enolate furnishes the adduct 80, thus completing the catalytic cycle. The authors performed two control studies to probe the involvement of the $\alpha$-amino radical 17 . The first study was to irradiate $N$-phenyltetrahydroisoquinoline $\mathbf{1 3}$ in the absence of the Michael acceptor under otherwise identical conditions. The dimer, $\mathbf{8 1}$, was formed as a mixture of diastereomers. The second study involved irradiation of $N$-phenyltetrahydroisoquinoline $\mathbf{1 3}$ only without degassing the reaction solution. The amide, $\mathbf{8 2}$, was produced instead. Both findings lend credence to the intermediacy of the $\alpha$-amino radical 17 .

The Yoon group independently discovered that the efficiency of the same Michael reaction was greatly improved in the presence of a Brønsted acid (Scheme 23) [90]. Some of the improvements included shorter reaction time, higher yields, and use of a weaker light source (CFL). The most effective acid catalysts, of which TFA was found to be optimal, lie within a narrow range of $\mathrm{p} K_{\mathrm{a}}$ values. The authors suggested that TFA protonates the enone $\mathbf{8 3}$, thus accelerating the addition of the $\alpha$-amino radical to the enone (84).

The Nishibayashi group reported that $\alpha$-amino radicals generated from a different class of amines, anilines 87, were also added intermolecularly to Michael acceptors 86 (Scheme 24) [91]. In this reaction, the Michael acceptors 86 were limited to those activated by two electron-withdrawing groups. $\left[\operatorname{Ir}(\mathrm{ppy})_{2}(\mathrm{dtbbpy})\right]\left(\mathrm{BF}_{4}\right)$ was found to be the most effective photocatalyst. Solvents were also critical to the outcome of the reaction; NMP produced much higher yields of the products 89 than DMF, while no products were formed in $\mathrm{MeCN}$ or $\mathrm{MeOH}$. The authors interrogated the intermediacy of the $\alpha$-amino radical $\mathbf{8 8}$ by treatment of diphenylmethylaniline with a Michael acceptor incorporating a cyclopropyl ring $\mathbf{9 5}$. The ringopening product 98 was isolated in $64 \%$ yield, which is consistent with the involvement of the $\alpha$-amino radical $\mathbf{8 8}$.

Oxygen has been suggested to play multiple roles in the oxidation of amines under photoredox conditions (vide supra). The Rueping group recently reported a new role that oxygen played in the intermolecular addition of $\alpha$-amino radicals to Michael acceptors (Scheme 25) [92]. Oxygen was found to act as a chemical switch to two competing reaction pathways from the same starting anilines. Irradiation of a degassed solution of aniline 99, 2-benzylidenemalononitrile 100, $5 \mathrm{~mol} \%$ $\left.\operatorname{Ir}(\text { ppy })_{2}(\mathrm{bpy})\right]\left(\mathrm{PF}_{6}\right)$ in $\mathrm{MeCN}$ furnished the typical Michael adduct 102. This result is similar to those reported by Pandey 
<smiles>CC(=O)CCC1c2ccccc2CCN1c1ccccc1</smiles>

Ru: 58\%; Ir: 68\%
$\mathrm{Ru}(\mathrm{bpy})_{3} \mathrm{Cl}_{2}$ or [Ir(ppy) $\left.)_{2}(\mathrm{dtbbpy})\right]\left(\mathrm{PF}_{6}\right)$

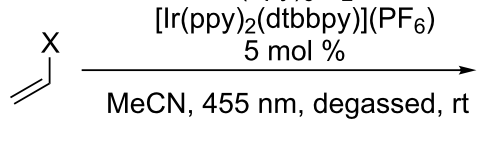<smiles></smiles><smiles>[X]CCC1c2ccccc2CCN1c1ccc([Y])cc1</smiles><smiles>N#CCCC1c2ccccc2CCN1c1ccccc1</smiles>

Ru: $27 \%$; Ir: $31 \%$

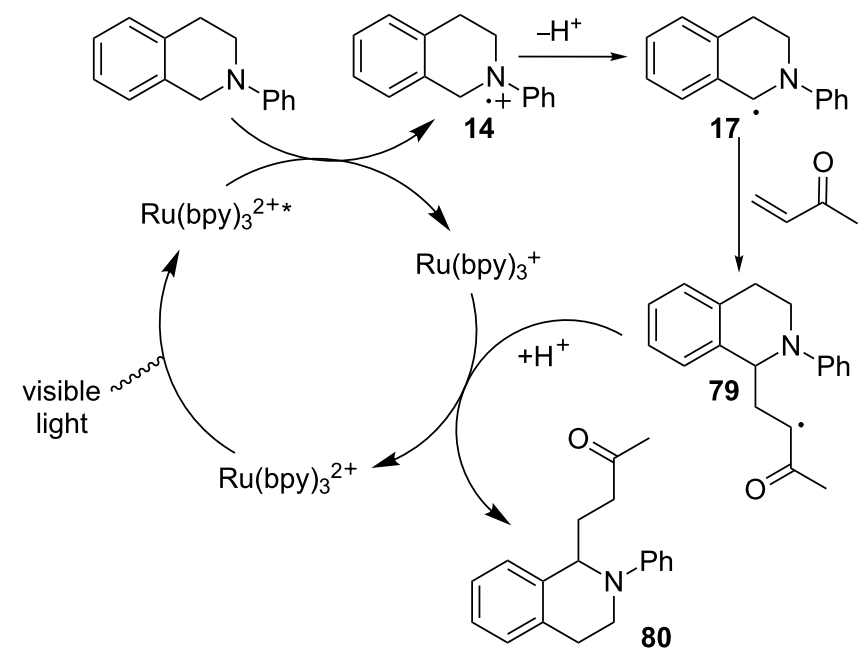<smiles>c1ccc(N2CCc3ccccc3C2C2c3ccccc3CCN2c2ccccc2)cc1</smiles>

81

$10 \%$

Ru: $61 \%$; Ir: $83 \%$

Ru: $53 \%$; Ir: $66 \%$

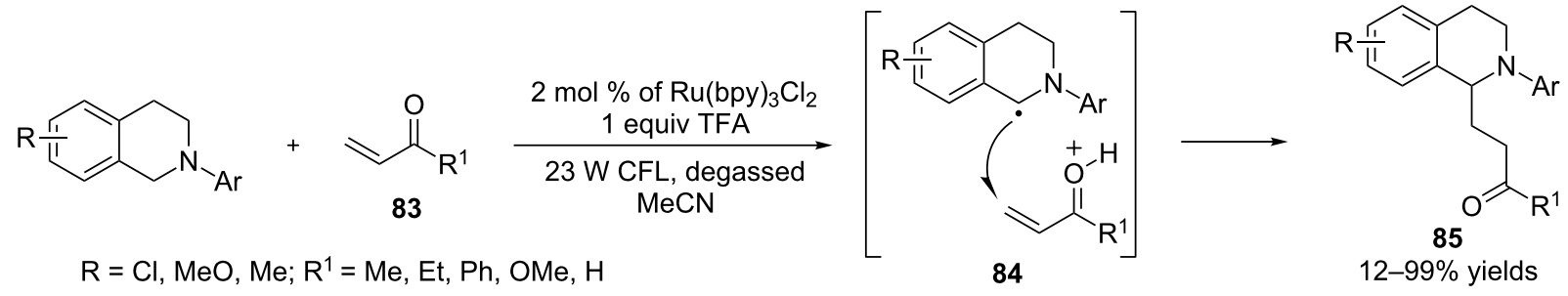



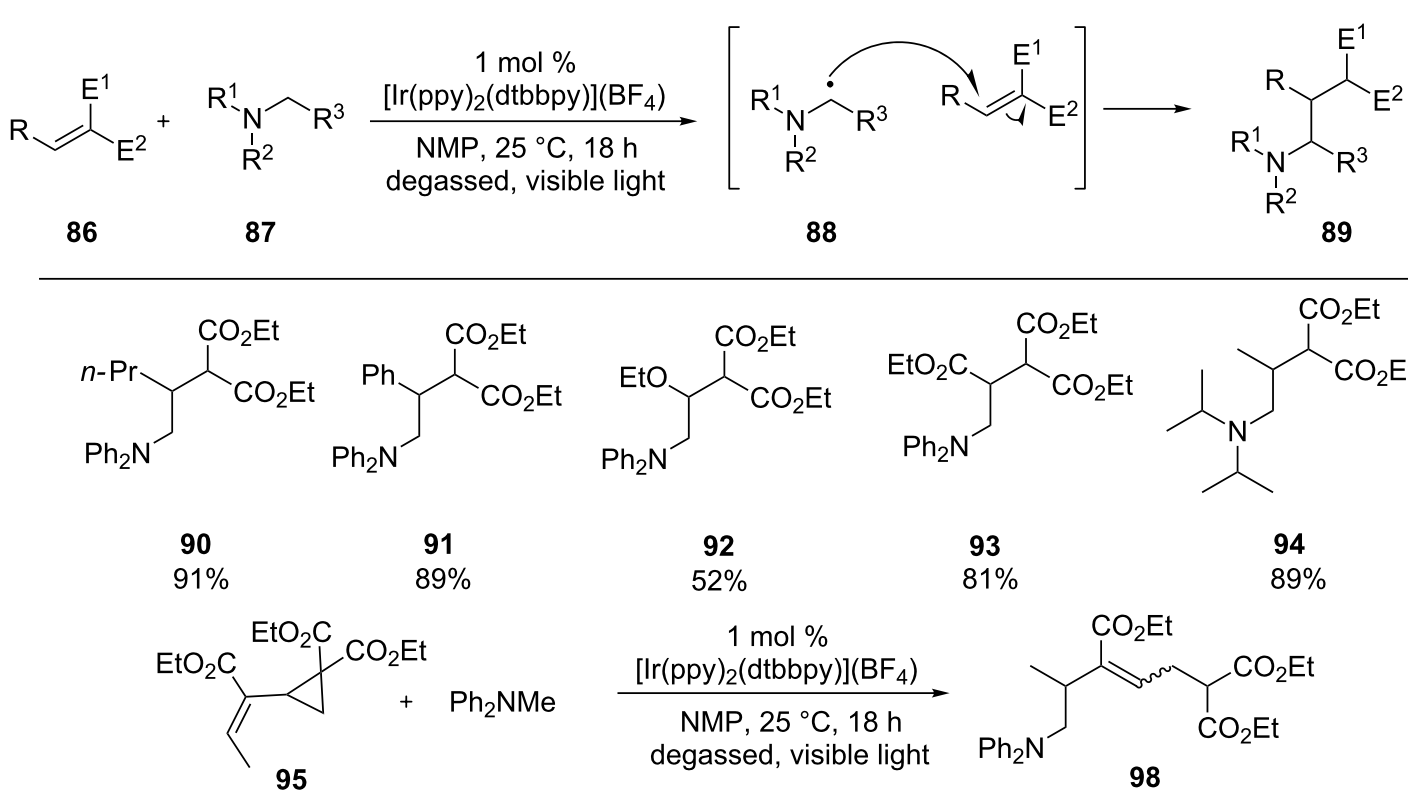<smiles>CCOC(=O)C(CNc1ccccc1)C(=O)OCC</smiles>

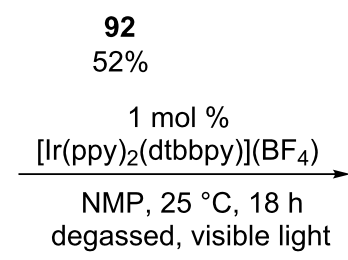<smiles>CCCC(C(=O)OCC)C(CNc1ccccc1)C(=O)OCC</smiles><smiles>CCOC(=O)C(CN(C(C)C)C(C)C)C(C)CC</smiles>

93 94 $81 \% \quad 89 \%$<smiles>CCOC(=O)C(=CC(CCOC)C(=O)OCC)C(C)CNc1ccccc1</smiles>
98

$(Z / E=1.5: 1)$ $64 \%$<smiles>CCCC(=CC=C(C(=O)OCC)C(C)CNc1ccccc1)C(C)CN</smiles>

Scheme 24: Conjugated addition of $\alpha$-amino radicals derived from anilines to Michael acceptors.

and Reiser [66], and Nishibayashi [91]. However, when the irradiation was conducted in the presence of air, a different reaction pathway occurred, resulting in the formation of $\mathrm{N}$-alkyltetrahydroquinoline 101. The two reaction pathways diverge from the radical intermediate $\mathbf{1 0 5}$ generated from the Michael addition of $\alpha$-amino radical 104 to 2-benzylidenemalononitrile $\mathbf{1 0 0}$. Without oxygen, the radical undergoes a one-electron reduction by $\operatorname{Ir}(\mathrm{II})$ to produce a stabilized anion, which is protonated to afford the Michael adduct 106. Alternatively, the radical is added onto arene to form a cyclohexadienyl radical 107. This step is reversible in the absence of oxygen. However, in the presence of oxygen, superoxide is formed via one-electron reduction of oxygen by $\operatorname{Ir}(\mathrm{II})$. The cyclohexadienyl radical 107 is converted to the cyclization product $\mathbf{1 0 8}$ irreversibly by giving one electron and one proton to the superoxide.

The Nishibayashi group also successfully trapped $\alpha$-amino radicals derived from $\mathrm{N}$-aryltetrahydroquinolines and $\mathrm{N}$-arylindolines using di-tert-butyl azodicarboxylate $\mathbf{1 1 0}$ to form $N, N$ acetal products 111 (Scheme 26) [93]. Functionalization of the $\mathrm{sp}^{3} \mathrm{C}-\mathrm{H}$ bond $\alpha$ to the nitrogen atom in tetrahydroquinolines and indolines via iminium ions is challenging because the corresponding iminium ions are enolizable and thus tend to tautomerize to enamines [94,95] and/or aromatize [96,97]. The authors adopted a strategy to bypass the iminium ions and use $\alpha$-amino radicals such as $\mathbf{1 1 2}$ instead to construct $\mathrm{C}-\mathrm{N}$ bonds. Treatment of $N, N$-acetal product 111 with Grignard reagents (Scheme 26, entry 1) or indoles in the presence of $\mathrm{TsOH}$ (Scheme 26, entry 2) provided nucleophilic substitution products at the $\alpha$ carbon. This provides an indirect approach for $\alpha-\mathrm{C}-\mathrm{H}$ functionalization of $\mathrm{N}$-aryltetrahydroquinolines and $N$-arylindolines. Based on the feasibility of oxidation of aromatic amines as well as reduction of di-tert-butyl azodicarboxylate (110) by the photoexcited Ir(III) complex [98,99], the authors favored a mechanism that does not involve the direct addition of $\alpha$-amino radical 112 to di-tert-butyl azodicarboxylate (110). Oxidation of $N$-phenyltetrahydroquinoline by the photoexcited $\operatorname{Ir}(\mathrm{III})$ complex followed by deprotonation provides $\alpha$-amino radical 112 with the concomitant formation of the Ir(II) complex. Di-tert-butyl azodicarboxylate (110) is reduced by the $\operatorname{Ir}(\mathrm{II})$ complex to generate radical anion $\mathbf{1 1 3}$, which couples with $\alpha$-amino radical 112 to yield nitrogen anion 114. Concurrently, the Ir(III) complex is regenerated. Protonation of $\mathbf{1 1 4}$ furnishes $N, N$-acetal 111. 


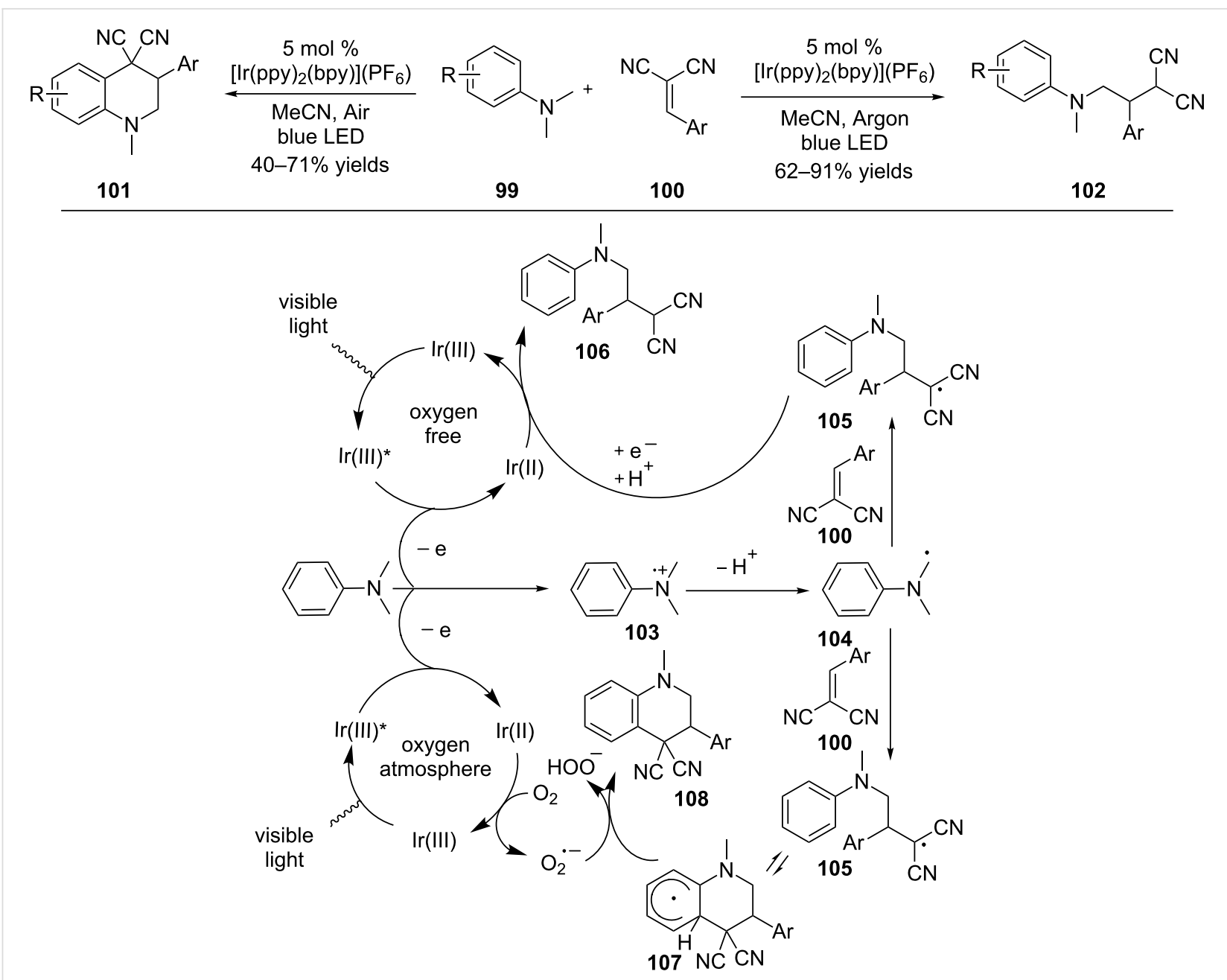

Scheme 25: Oxygen switch between two pathways involving a-amino radicals.

$\alpha$-Amino radicals have been mainly used in conjugate addition reactions. Recently, the MacMillan group has nicely expanded the scope of the reactions to include addition of the radicals to aryl rings (Scheme 27) [100]. Using $\operatorname{Ir}(\mathrm{ppy})_{3}$ as the photocatalyst and a $26 \mathrm{~W}$ fluorescent light bulb as the light source, cyclic amines with a variety of ring sizes and acyclic amines underwent the $\alpha$-arylation reaction to provide benzylic amines. The arylating reagents were benzonitriles substituted with an electron-withdrawing group. The nitrile group functioned as the leaving group. In some classes of five-membered heteroaromatics, a chloride was capable of replacing the nitrile group as the leaving group.

The authors proposed a mechanistic pathway that is initiated by oxidative quenching of the photoexcited state of $\operatorname{Ir}(\mathrm{ppy})_{3}$ by benzonitrile 121 to generate radical anion 123 and $\operatorname{Ir}^{4+}(\mathrm{ppy})_{3}$ (Scheme 28). Amine 122 is then oxidized to amine radical cation 124 by $\mathrm{Ir}^{4+}(\text { ppy })_{3}$ that is reduced to the initial catalyst, $\operatorname{Ir}(\mathrm{ppy})_{3}$. Deprotonation of amine radical cation $\mathbf{1 2 4}$ by $\mathrm{NaOAc}$ produces $\alpha$-amino radical $\mathbf{1 2 5}$, which is coupled with radical anion 123 to form the key $\mathrm{C}-\mathrm{C}$ bond in $\mathbf{1 2 6}$. Finally, aromatization via expulsion of the nitrile group provides benzylic amine 127.

\section{Cleavage of $\mathrm{C}-\mathrm{C}$ and $\mathrm{N}-\mathrm{N}$ bonds}

The dominant reaction pathway involving the photogenically formed amine radical cations is deprotonation at the carbon $\alpha$ to the nitrogen atom to produce the strongly reducing $\alpha$-amino radicals (e.g., 128 to 129). $\alpha$-Amino radicals can be then intercepted by Michael acceptors or undergo one-electron oxidation to yield iminium ions (vide supra). An alternative yet much less exploited reaction pathway concerning amine radical cations 129 is the cleavage of the $\mathrm{C}-\mathrm{C}$ bond $\alpha$ to the nitrogen atom to generate a neutral carbon radical (e.g., 130) and an iminium ion (e.g., 131). The iminum ion is subsequently reduced to $\alpha$-amino radical 132 by $\mathrm{Ru}(\mathrm{I})$. Back in 1986, the Whitten group established this pathway by irradiation of three substituted tertiary amines with $\mathrm{Ru}\left[4,4^{\prime}-\mathrm{CO}_{2} \mathrm{Et}(\mathrm{bpy})\right]_{3}\left(\mathrm{PF}_{6}\right)_{2}$ respectively using 


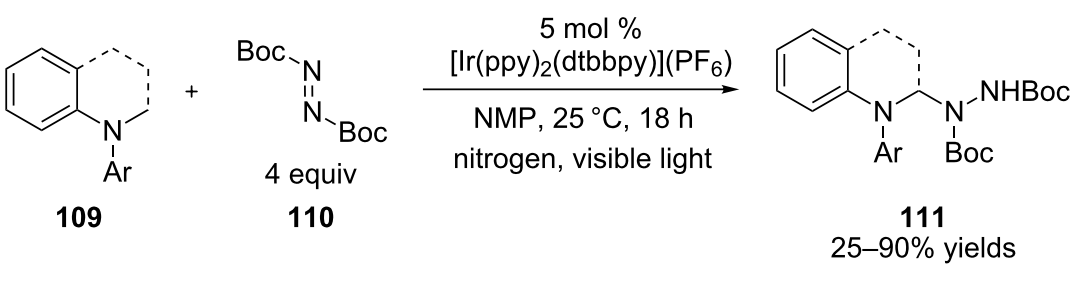

(2)

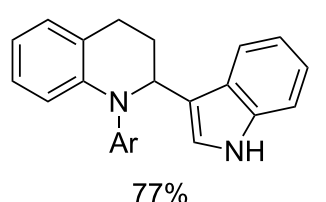

$77 \%$

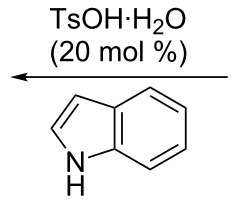<smiles>CC(C)(C)ONC(=O)NC1CCc2ccccc2N1C(=O)OCc1ccccc1</smiles>

$\mathrm{Ar}=4-(t-\mathrm{Bu}) \mathrm{Ph}$<smiles>[R10][R4]([H])(C)Br</smiles><smiles>[R]C1CCc2ccccc2N1[Al]</smiles>

74-93\% $\mathrm{R}=$ allyl, $\mathrm{Bn}, \mathrm{Ph}$, ethynyl

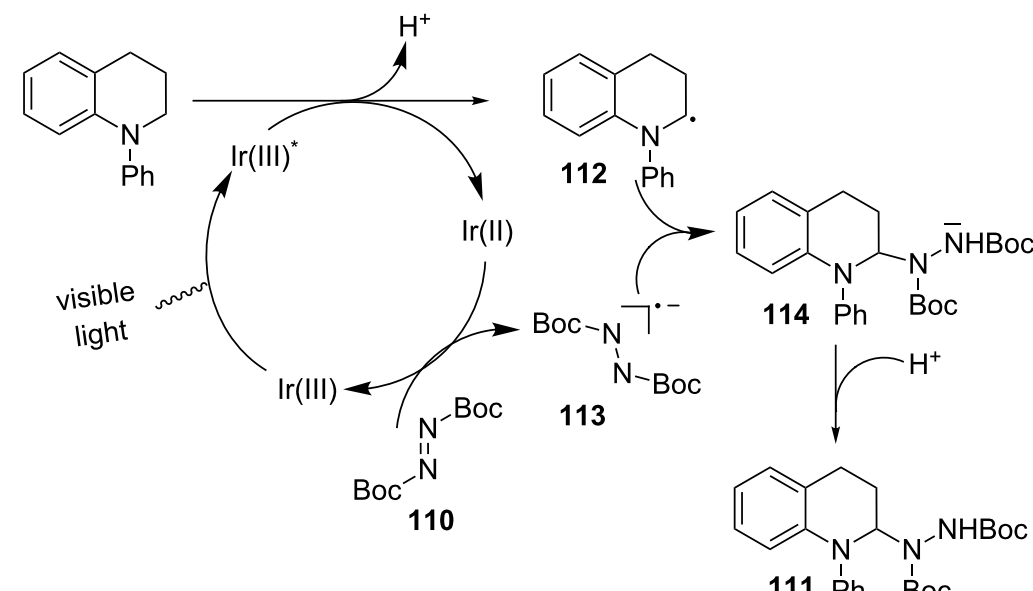

Scheme 26: Interception of $\alpha$-amino radicals by azodicarboxylates.
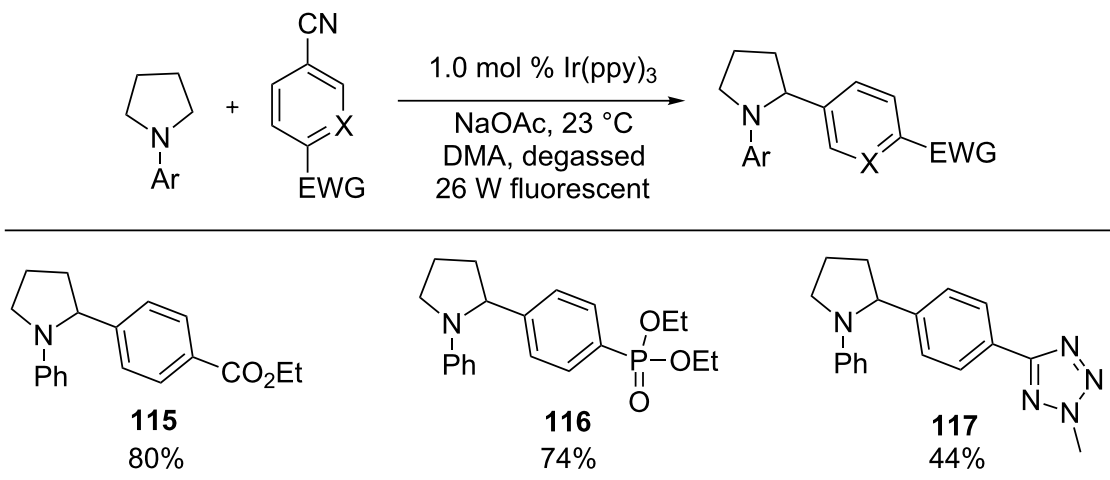<smiles>c1ccc(N2CCCC2c2ccncc2)cc1</smiles>

118 $72 \%$<smiles>Pc1ccccc1</smiles>

119

$49 \%$

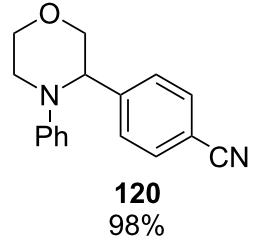




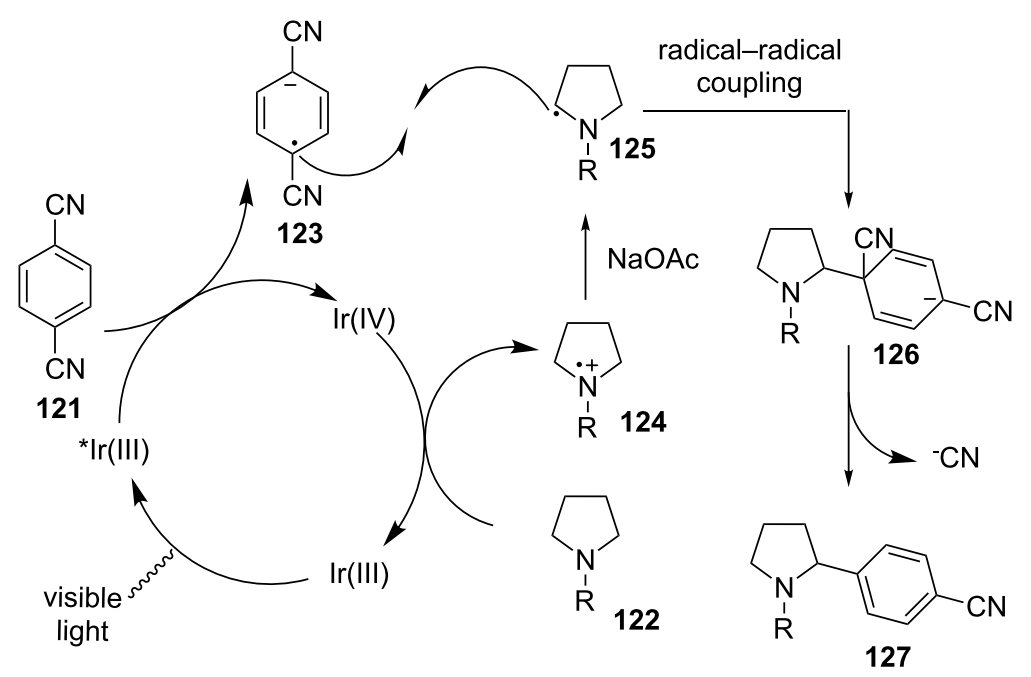

Scheme 28: Plausible mechanism for $\alpha$-arylation of amines.

visible light (Scheme 29) [101]. The identity of carbon radicals 130a and 130b was established by trapping them with a spin trap and then analyzing using EPR. Additionally, detection of benzaldehyde by HPLC and VPC provided further evidence for their formation. In contrast, no products from the amine half (e.g., 131 and 132) were detected.

$\mathrm{Li}$ and Wang recently applied this cleavage reaction to 1,2-diamines, simultaneously generating two classes of synthetically useful intermediates, iminium ions (e.g., 133, Scheme 30) and $\alpha$-amino radicals (e.g., 134, Scheme 30) [102]. The authors then exploited the synthetic utility of these two classes of intermedi- ates. Irradiation of nitroalkanes, TMEDA, and $\mathrm{Ru}(\mathrm{bpy})_{3} \mathrm{Cl}_{2}$ in 1 atm oxygen afforded the aza-Henry products 135 , presumably by trapping the $\mathrm{Me}_{2} \mathrm{~N}=\mathrm{CH}_{2}$ iminium ion $\mathbf{1 3 3}$ that is formed by cleaving TMEDA (Scheme 30, entry 1). Separately, irradiation of 2-hydroxyethylacrylate (HEA), TMEDA, and $\mathrm{Ru}(\mathrm{bpy})_{3} \mathrm{Cl}_{2}$ in air produced a polymer incorporating a dimethylamino group (136, Scheme 30, entry 2). The dimethylamino radical, the other intermediate generated by cleaving TMEDA, most likely induced the polymerization. The chemistries involving the iminium ions and $\alpha$-amino radicals, generated under visible light photoredox conditions, are often limited by the substrate scope of the amine precursors, since aromatic
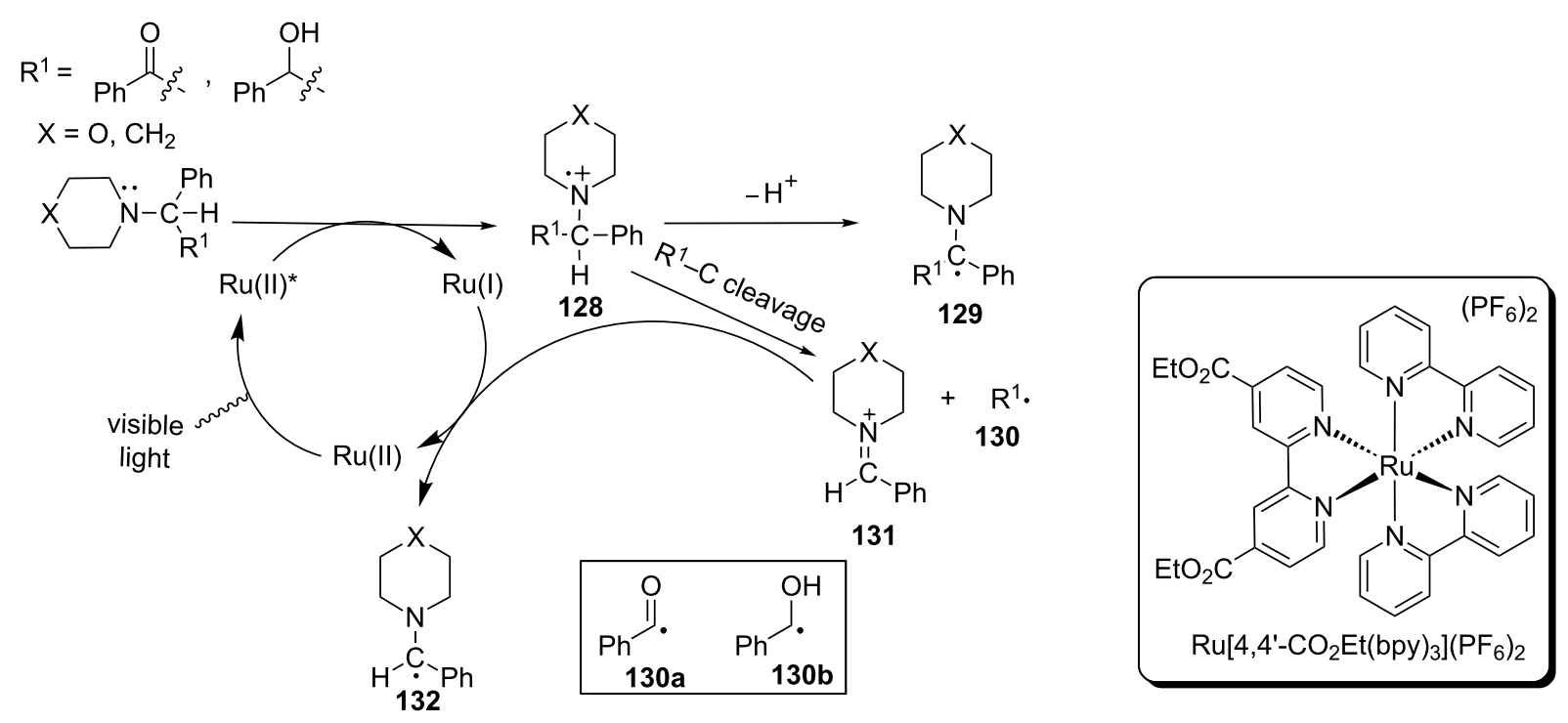

Scheme 29: Photoinduced C-C bond cleavage of tertiary amines. 


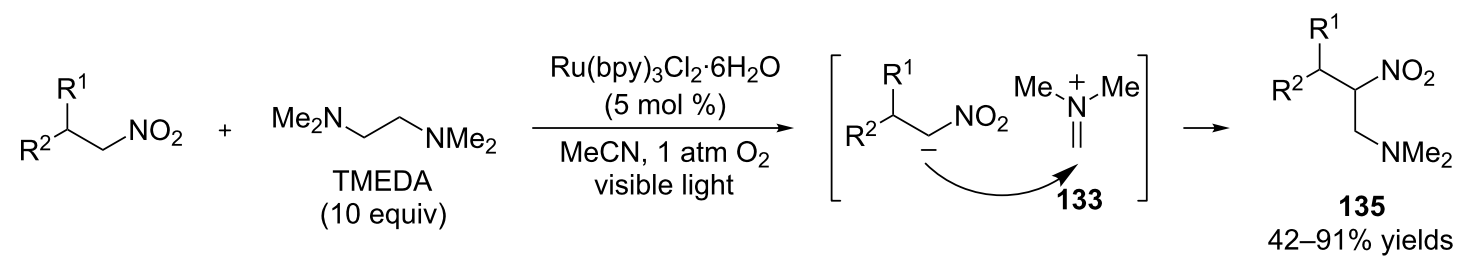<smiles>C[N+](=O)[O-]</smiles>

$72 \%$<smiles>COc1ccccc1CC(CN)[N+](=O)[O-]</smiles>

$72 \%$<smiles>CN(C)CC(Cc1c[nH]c2ccccc12)[N+](=O)[O-]</smiles>
$91 \%$<smiles>CN(C)CC(Cc1ccco1)[N+](=O)[O-]</smiles>
$63 \%$

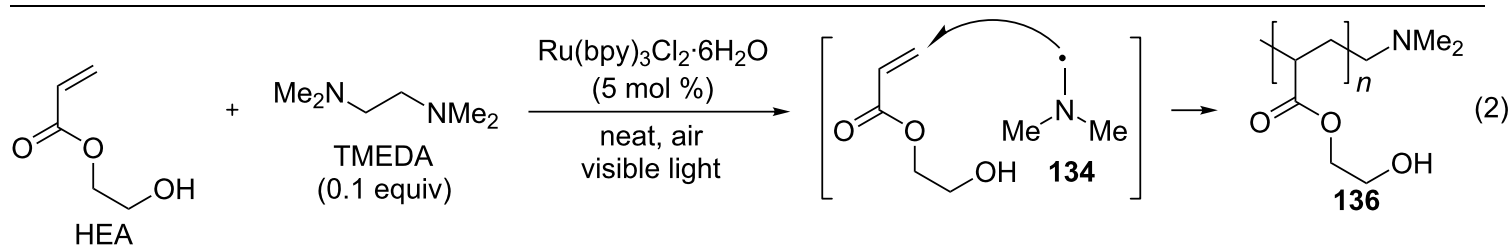

Scheme 30: Photoredox cleavage of C-C bonds of 1,2-diamines.

amines are typically required (vide supra). The cleavage reaction, as demonstrated by Li and Wang's work, has the potential to produce different types of iminium ions and $\alpha$-amino radicals that are not accessible by oxidizing amines directly.

The reaction is proposed to proceed through the initial oxidation of TMEDA to amine radical cation 137 by the photoexcited state of the $\mathrm{Ru}(\mathrm{II})$ complex (Scheme 31 ). Amine radical cation 137 subsequently induces cleavage of the $\mathrm{C}-\mathrm{C}$ bond $\alpha$ to the nitrogen atom to form iminium ion $\mathbf{1 3 3}$ and $\alpha$-amino radical 134 concurrently. By carefully selecting reagents/conditions, either reactive intermediate can selectively participate in the designated reaction. As shown in Li and Wang's work, iminium ion $\mathbf{1 3 3}$ is intercepted by nitroalkane to afford the aza-Henry product $\mathbf{1 3 5}$ while $\alpha$-amino radical $\mathbf{1 3 4}$ is used to initialize radical polymerization of HEA.

Because of ring strain, cyclopropanes are prone to ring opening via cleavage of one of the three $\mathrm{C}-\mathrm{C}$ bonds. The resulting reactive intermediates have been shown to participate in a number of synthetic/mechanistic applications [103,104]. One of these applications is a radical clock, which is centered on the cyclopropylcarbonyl to homoallyl radical rearrangement [105]. A homologous rearrangement based on the amine radical cation of $\mathrm{N}$-cyclopropylanilines permits cleavage of the $\mathrm{C}-\mathrm{C}$ bond $\alpha$ to the nitrogen atom but generating a $\gamma$-carbon radical iminium ion (distonic ion) [106]. We have applied $\mathrm{Ru}(\mathrm{bpz})_{3}\left(\mathrm{PF}_{6}\right)_{2}$-catalyzed photooxidation of $\mathrm{N}$-cyclopropylanilines to induce this
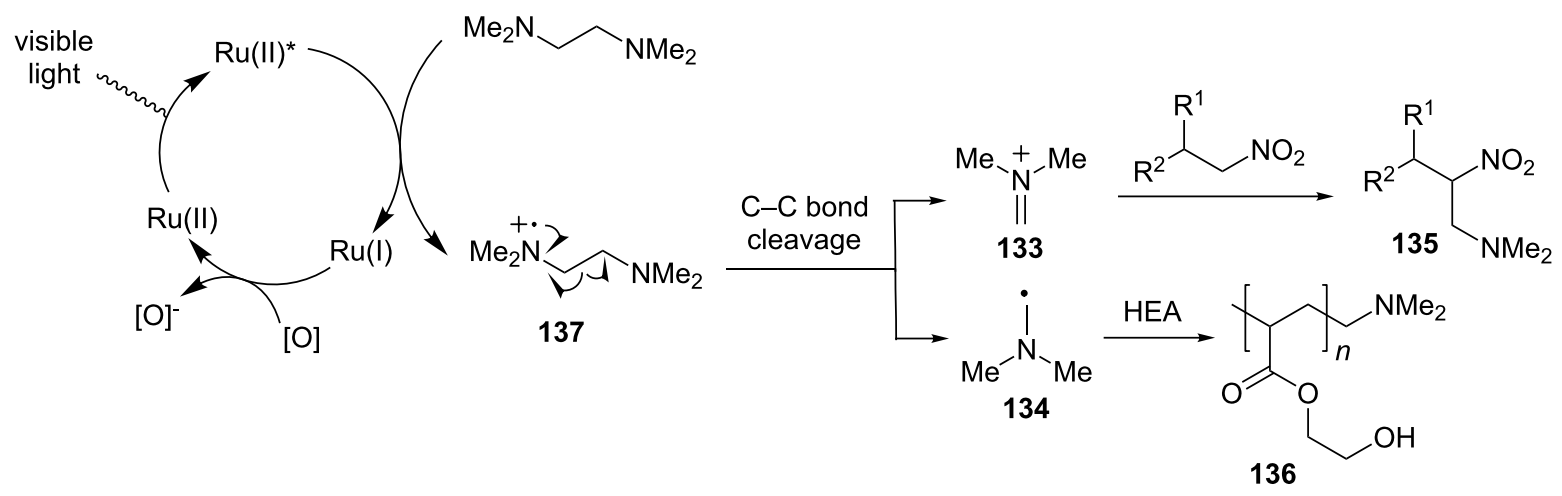

Scheme 31: Proposed mechanism photoredox cleavage of $C-C$ bonds. 
rearrangement reaction. The resulting distonic ion was then intercepted by alkenes to produce [3+2] annulation products (Scheme 32) [107]. An aryl group on the amine was required for the reaction. Both mono- and bicyclic cyclopropylanilines were viable substrates to provide the annulation products in good to excellent yields. The former gave little to poor diastereoselectivity whereas the later produced modest diastereoselectivity. The reaction has $100 \%$ atom economy. It is also overall redox-neutral and thus does not require an external oxidant.

We believe that the annulation reaction proceeds first via reductive quenching of the photoexcited state of $\mathrm{Ru}(\mathrm{II})$ by cyclopropylaniline 147 to generate amine radical cation 148 and $\mathrm{Ru}(\mathrm{I})$ (Scheme 33). Amine radical cation 148 then triggers the ring opening to release the ring strain while producing a distonic ion 149 with a primary radical. Distonic ion 149 is added via a Giese-type radical addition to an alkene, yielding a more stable distonic ion $\mathbf{1 5 1}$ with a secondary radical. Intramolecular addition of the secondary radical to the iminium ion furnishes a new amine radical cation 152. Finally, amine radical cation $\mathbf{1 5 2}$ is reduced by $\mathrm{Ru}(\mathrm{I})$ to provide the annulation prod- uct 153 and regenerate $\mathrm{Ru}(\mathrm{II})$, thus completing the catalytic cycle.

Our group also realized cleavage of $\mathrm{N}-\mathrm{N}$ bonds by irradiation of aromatic hydrazines or hydrazides in the presence of $\mathrm{Ru}(\mathrm{bpz})_{3}\left(\mathrm{PF}_{6}\right)_{2}$ and air (Scheme 34) [108]. A $13 \mathrm{~W}$ compact fluorescent light was sufficient as the light source. $N, N$-disubstituted hydrazines and hydrazides were suitable substrates provided that at least one of the two substituents on the nitrogen atom was an aryl group. Electron-richer hydrazines were found to be more reactive than hydrazides. This is consistent with our expectation that, similar to amines, hydrazines and hydrazides act as an electron donor to reductively quench the photoexcited $\mathrm{Ru}(\mathrm{II})$ complex. The photoexcited state of $\mathrm{Ru}(\mathrm{bpz})_{3}\left(\mathrm{E}_{1 / 2} * \mathrm{II} / \mathrm{I}=\right.$ $1.45 \mathrm{~V}$ vs SCE) is more oxidizing than that of $\mathrm{Ru}(\mathrm{bpy})_{3}$ $\left(\mathrm{E}_{1 / 2} * \mathrm{II} / \mathrm{I}=0.77 \mathrm{~V}\right.$ vs SCE$)$. However, the two catalysts showed a divergent pattern of reactivity in the reaction. $\mathrm{Ru}(\mathrm{bpy})_{3}$ was the more active catalyst for hydrazines, whereas $\mathrm{Ru}(\mathrm{bpz})_{3}$ was more active for hydrazides. The use of $\mathrm{MeOH}$ in addition to $\mathrm{CH}_{3} \mathrm{CN}$ significantly shortened the reaction time for less reactive hydrazides, but showed little effect for hydrazines. We believe that the cleavage reaction is initialized via the oxidation<smiles>[R4]c1ccc(NC2CC2)cc1</smiles>

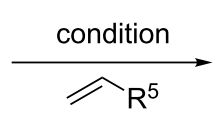<smiles>[R4]c1ccc(NC2CCCC2[R8])cc1</smiles>

condition: $2 \mathrm{~mol} \%\left[\mathrm{Ru}(\mathrm{bpz})_{3}\right]\left(\mathrm{PF}_{6}\right)_{2}, 13 \mathrm{~W}$ fluorescent bulb, degassed $\mathrm{CH}_{3} \mathrm{NO}_{2}$, rt

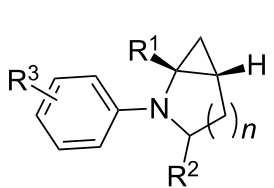<smiles>[R]C=CC(C)C</smiles>

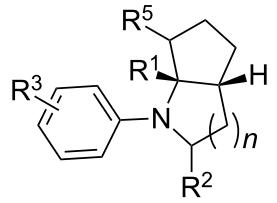

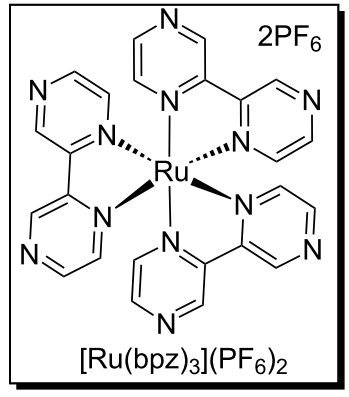<smiles>c1ccc(NC2CCCC2c2ccccc2)cc1</smiles>

138

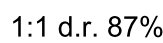<smiles>CCCCOc1ccc(N2CC[C@@H]3CC[C@H](c4ccccc4)[C@]32C)cc1</smiles>

143<smiles>c1ccc(C2CCCC2Nc2cccnc2)cc1</smiles>

139

1:1 d.r. $71 \%$

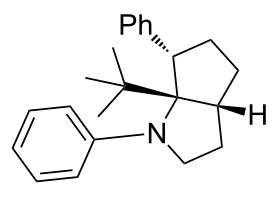

144

$>25: 1$ d.r. $28 \%$<smiles>c1ccc(-c2ccccc2NC2CCCC2c2ccccc2)cc1</smiles>

140<smiles>Brc1ccccc1[C@H]1CCC[C@H]1Nc1ccccc1</smiles>

141<smiles>C(=C/[C@H]1CCC[C@H]1Nc1ccccc1)\c1ccccc1</smiles>

142

$3: 2$ d.r. $80 \%$

$2: 1$ d.r. $82 \%$

2:1 d.r. $40 \%$ 


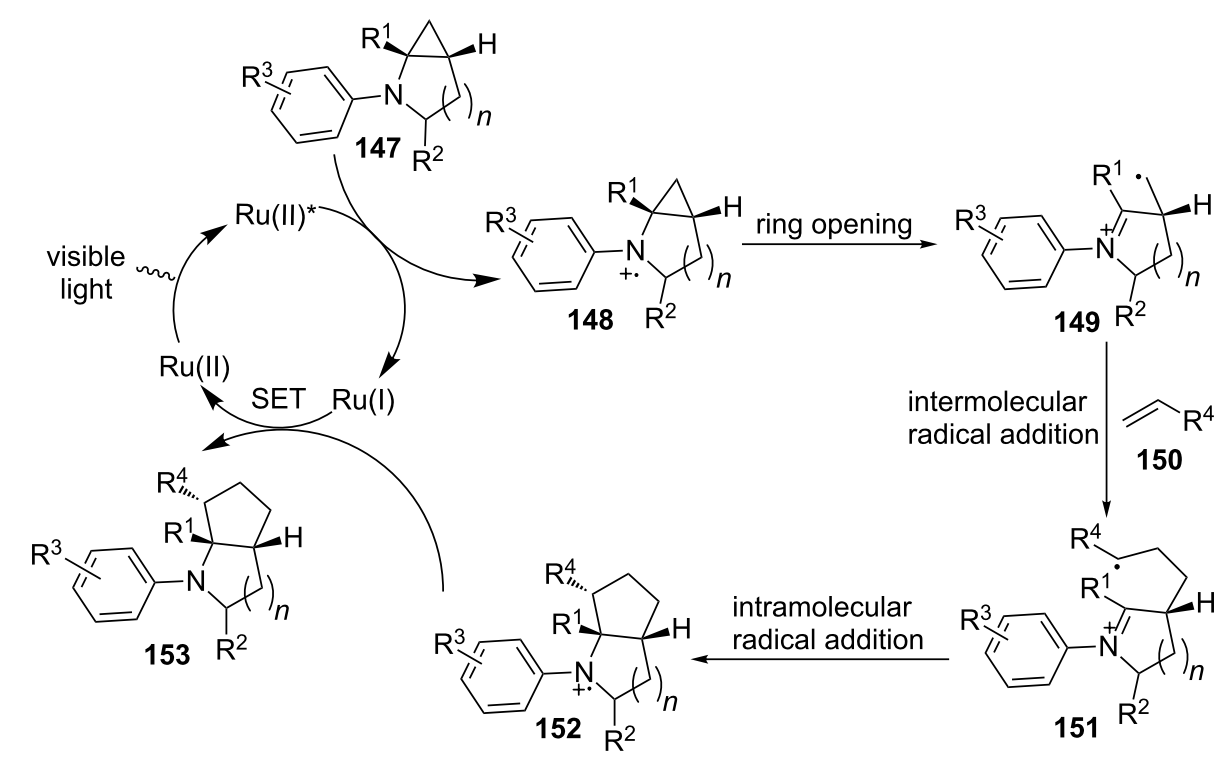

Scheme 33: Proposed mechanism for intermolecular [3+2] annulation.
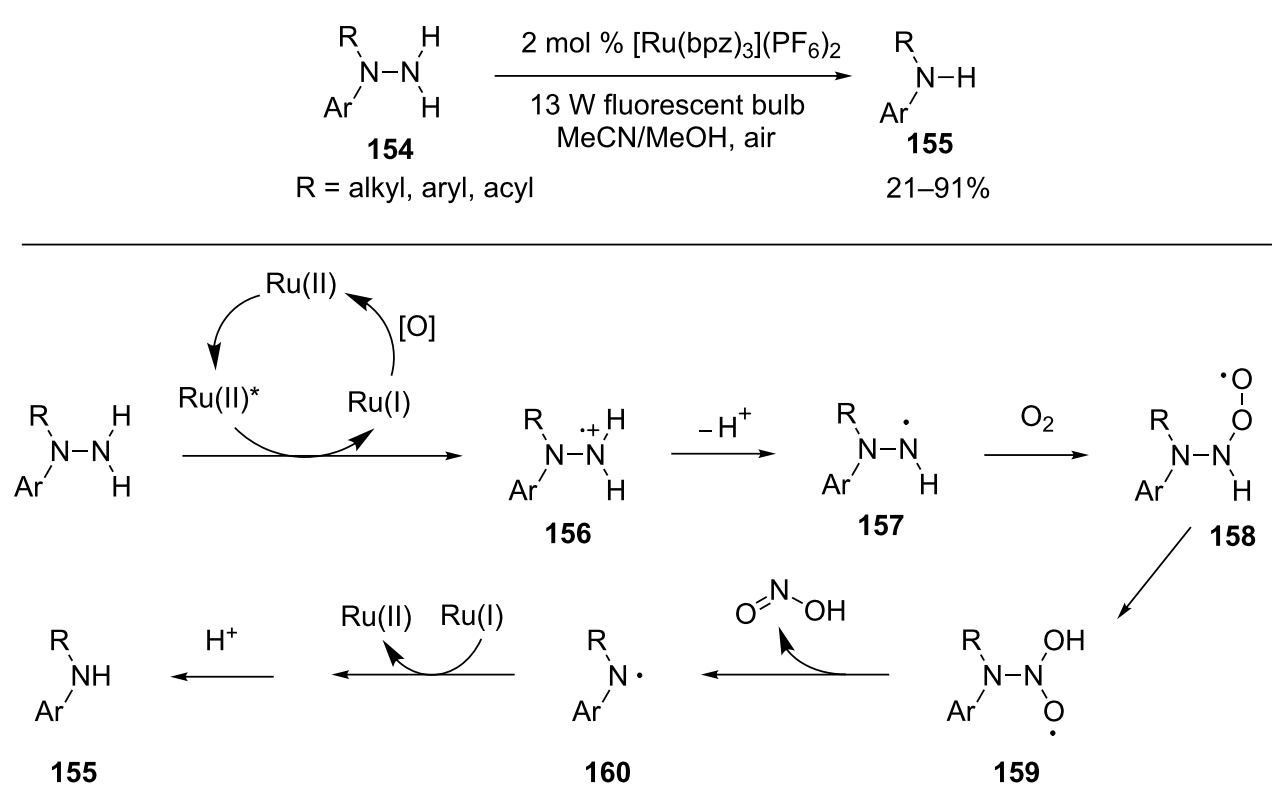

Scheme 34: Photoinduced clevage of $\mathrm{N}-\mathrm{N}$ bonds of aromatic hydrazines and hydrazides.

of hydrazines or hydrazides to a amine radical cation 156 by the photoexcited Ru(II) complex. Deprotonation of the amine radical cation 156 produces a neutral nitrogen radical 157 that reacts with oxygen to furnish the radical 158. The radical 158 then rearranges to a new oxygen-based radical $\mathbf{1 5 9}$, which undergoes a cleavage reaction to yield nitrous acid and a secondary amine radical 160. Finally, one-electron reduction of the amine radical by $\mathrm{Ru}(\mathrm{I})$, followed by protonation provides a secondary amine 155.

\section{Conclusion}

Visible light photoredox catalysis provides a unique way to activate small molecules such as amines. The dual nature of the photocatalyst's photoexcited state as both oxidant and reductant allows accepting or donating one electron strictly dependent upon the small molecules encountered. Amines typically act as an electron donor to reductively quench the photoexcited state while they are oxidized to the corresponding amine radical cations. The resulting nitrogen radical cations are highly useful 
reactive intermediates that are capable of initializing multiple downstream pathways leading to diverse synthetic intermediates such as electrophilic iminium ions, nucleophilic $\alpha$-amino radicals, and distonic ions possessing both an iminium ion and a carbon radical. Interception of these intermediates allows a variety of synthetic transformations to produce a diverse array of amines. Moreover, visible light photoredox catalysis has been merged with other types of catalysis, including enamine catalysis, $\mathrm{N}$-heterocyclic carbene (NHC) catalysis, or copper acetylide formation. This dual catalysis approach has significantly expanded the type of bonds that can be formed, particularly bonds formed asymmetrically. In summary, the utility of amine radical cations formed via photooxidation of the amines has been amply demonstrated in a number of synthetic methods. With the organic community's increasing interest in visible light photoredox catalysis, new and innovative applications of this reactive intermediate will continue to develop.

\section{References}

1. Chow, Y. L.; Danen, W. C.; Nelson, S. F.; Rosenblatt, D. H. Chem. Rev. 1978, 78, 243-274. doi:10.1021/cr60313a003

2. Stella, L. Angew. Chem., Int. Ed. Engl. 1983, 22, 337-350. doi:10.1002/anie.198303373

3. Bauld, N. L. Tetrahedron 1989, 45, 5307-5363. doi:10.1016/S0040-4020(01)89486-2

4. Schmittel, M.; Burghart, A. Angew. Chem., Int. Ed. Engl. 1997, 36, 2550-2589. doi:10.1002/anie.199725501

5. Fallis, A. G.; Brinza, I. M. Tetrahedron 1997, 53, 17543-17594. doi:10.1016/S0040-4020(97)10060-6

6. Moeller, K. D. Tetrahedron 2000, 56, 9527-9554 doi:10.1016/S0040-4020(00)00840-1

7. Hoffmann, N. Pure Appl. Chem. 2007, 79, 1949-1958. doi:10.1351/pac200779111949

8. Stella, L. Nitrogen-centered radicals. In Radicals in Organic Synthesis; Renaud, P.; Sibi, M. P., Eds.; Wiley-VCH: Weinheim, Germany, 2001; Vol. 2, pp 407-426. doi:10.1002/9783527618293.ch45

9. Chiba, T.; Takata, Y. J. Org. Chem. 1977, 42, 2973-2977. doi:10.1021/jo00438a005

10. Shono, T.; Matsumura, Y.; Tsubata, K. J. Am. Chem. Soc. 1981, 103, 1172-1176. doi:10.1021/ja00395a029

11. Baslé, O.; Borduas, N.; Dubois, P.; Chapuzet, J. M.; Chan, T.-H.; Lessard, J.; Li, C.-J. Chem.-Eur. J. 2010, 16, 8162-8166. doi:10.1002/chem.201000240

12. Tsang, A. S.-K.; Todd, M. H. Tetrahedron Lett. 2009, 50, 1199-1202. doi:10.1016/j.tetlet.2008.12.101

13. Richter, T.; Mancheño, O. G. Eur. J. Org. Chem. 2010, 4460-4467. doi:10.1002/ejoc.201000548

14. Shu, X.-Z.; Xia, X.-F.; Yang, Y.-F.; Ji, K.-G.; Liu, X.-Y.; Liang, Y.-M. J. Org. Chem. 2009, 74, 7464-7469. doi:10.1021/jo901583r

15. Murahashi, S.-I.; Zhang, D. Chem. Soc. Rev. 2008, 37, 1490-1501. doi:10.1039/b706709g

16. Li, C.-J. Acc. Chem. Res. 2009, 42, 335-344. doi:10.1021/ar800164n

17. Boess, E.; Schmitz, C.; Klussmann, M. J. Am. Chem. Soc. 2012, 134, 5317-5325. doi:10.1021/ja211697s

18. Ratnikov, M. O.; Doyle, M. P. J. Am. Chem. Soc. 2013, 135, 1549-1557. doi:10.1021/ja3113559
19. Cho, D. W.; Yoon, U. C.; Mariano, P. S. Acc. Chem. Res. 2011, 44 , 204-215. doi:10.1021/ar100125j

20. Pandey, G.; Gadre, S. R. ARKIVOC 2003, 45-54. doi:10.3998/ark.5550190.0004.306

21. Hoshikawa, T.; Yoshioka, S.; Kamijo, S.; Inoue, M. Synthesis 2013, 45, 874-887. doi:10.1055/s-0032-1318325

22. Shi, L.; Xia, W. Chem. Soc. Rev. 2012, 41, 7687-7697. doi:10.1039/c2cs35203f

23. Maity, S.; Zheng, N. Synlett 2012, 23, 1851-1856. doi:10.1055/s-0032-1316592

24. Campagana, S.; Puntoriero, F.; Nastasi, F.; Bergamini, G.; Balzani, V. Top. Curr. Chem. 2007, 280, 117-214. doi:10.1007/128_2007_133

25. Juris, A.; Balzani, V.; Barigelletti, F.; Campagna, S.; Belser, P.; von Zelewsky, A. Coord. Chem. Rev. 1988, 84, 85-277. doi:10.1016/0010-8545(88)80032-8

26. Kalyanasundaram, K. Coord. Chem. Rev. 1982, 46, 159-244. doi:10.1016/0010-8545(82)85003-0

27. Lowry, M. S.; Bernhard, S. Chem.-Eur. J. 2006, 12, 7970-7977. doi:10.1002/chem.200600618

28. Flamigni, L.; Barbieri, A.; Sabatini, C.; Ventura, B.; Barigelletti, F. Top. Curr. Chem. 2007, 281, 143-203. doi:10.1007/128_2007_131

29. Hedstrand, D. M.; Kruizinga, W. H.; Kellogg, R. M. Tetrahedron Lett. 1978, 19, 1255-1258. doi:10.1016/S0040-4039(01)94515-0

30. Neumann, M.; Füldner, S.; König, B.; Zeitler, K. Angew. Chem., Int. Ed. 2011, 50, 951-954. doi:10.1002/anie.201002992

31. Meyer, T. J. Acc. Chem. Res. 1989, 22, 163-170. doi:10.1021/ar00161a001

32. Bard, A. J.; Fox, M. A. Acc. Chem. Res. 1995, 28, 141-145. doi:10.1021/ar00051a007

33. Lehn, J. M.; Ziessel, R. Proc. Natl. Acad. Sci. U. S. A. 1982, 79, 701-704. doi:10.1073/pnas.79.2.701

34. Willner, I.; Maidan, R.; Mandler, D.; Duerr, H.; Doerr, G.; Zengerle, K. J. Am. Chem. Soc. 1987, 109, 6080-6086. doi:10.1021/ja00254a029

35. Prier, C. K.; Rankic, D. A.; MacMillan, D. W. C. Chem. Rev. 2013, 113, 5322-5363. doi:10.1021/cr300503r

36. Yoon, T. P.; Ischay, M. A.; Du, J. Nat. Chem. 2010, 2, 527-532. doi:10.1038/nchem.687

37. Tucker, J. W.; Stephenson, C. R. J. J. Org. Chem. 2012, 77, 1617-1622. doi:10.1021/jo202538x

38. Xuan, J.; Xiao, W.-J. Angew. Chem., Int. Ed. 2012, 51, 6828-6838. doi:10.1002/anie.201200223

39. Telpý, F. Collect. Czech. Chem. Commun. 2011, 76, 859-917. doi:10.1135/cccc2011078

40. Narayanam, J. M. R.; Stephenson, C. R. J. Chem. Soc. Rev. 2011, 40, 102-113. doi:10.1039/b913880n

41. Zeitler, K. Angew. Chem., Int. Ed. 2009, 48, 9785-9789. doi:10.1002/anie.200904056

42. Xi, Y.; Yi, H.; Lei, A. Org. Biomol. Chem. 2013, 11, 2387-2403. doi:10.1039/c3ob40137e

43. Gould, I. R.; Ege, D.; Moser, J. E.; Farid, S. J. Am. Chem. Soc. 1990, 112, 4290-4301. doi:10.1021/ja00167a027

44. Kellett, M. A.; Whitten, D. G.; Gould, I. R.; Bergmark, W. R. J. Am. Chem. Soc. 1991, 113, 358-359. doi:10.1021/ja00001a052

45. DeLaive, P. J.; Lee, J. T.; Springtschnik, H. W.; Abruña, H.; Meyer, T. J.; Whitten, D. G. J. Am. Chem. Soc. 1977, 99, 7094-7097. doi:10.1021/ja00463a070

46. DeLaive, P. J.; Foreman, T. K.; Giannotti, C.; Whitten, D. G. J. Am. Chem. Soc. 1980, 102, 5627-5631. doi:10.1021/ja00537a037 
47. Mashraqui, S. H.; Kellog, R. M. Tetrahedron Lett. 1985, 26, 1453-1456. doi:10.1016/S0040-4039(00)99069-5

48. Fukuzumi, S.; Mochizuki, S.; Tanaka, T. J. Phys. Chem. 1990, 94, 722-726. doi:10.1021/j100365a039

49. Willner, I.; Tsfania, T.; Eichen, Y. J. Org. Chem. 1990, 55, 2656-2662. doi:10.1021/jo00296a023

50. Narayanam, J. M. R.; Tucker, J. W.; Stephenson, C. R. J. J. Am. Chem. Soc. 2009, 131, 8756-8757. doi:10.1021/ja9033582

51. Nguyen, J. D.; D'Amato, E. M.; Narayanam, J. M. R.; Stephenson, C. R. J. Nat. Chem. 2012, 4, 854-859. doi:10.1038/nchem.1452

52. Tucker, J. W.; Nguyen, J. D.; Narayanam, J. M. R.; Krabbe, S. W.; Stephenson, C. R. J. Chem. Commun. 2010, 46, 4985-4987. doi:10.1039/c0cc00981d

53. Tucker, J. W.; Stephenson, C. R. J. Org. Lett. 2011, 13, 5468-5471. doi:10.1021/ol202178t

54. Kim, H.; Lee, C. Angew. Chem., Int. Ed. 2012, 51, 12303-12306. doi:10.1002/anie.201203599

55. Chen, Y.; Kamlet, A. S.; Steinman, J. B.; Liu, D. R. Nat. Chem. 2011, 3, 146-153. doi:10.1038/nchem.932

56. Nelson, S. F.; Ippoliti, J. T. J. Am. Chem. Soc. 1986, 108, 4879-4881. doi:10.1021/ja00276a028

57. Lewis, F. D. Acc. Chem. Res. 1986, 19, 401-405. doi:10.1021/ar00132a004

58. Parker, V. D.; Tilset, M. J. Am. Chem. Soc. 1991, 113, 8778-8781. doi:10.1021/ja00023a026

59. Dombrowski, G. W.; Dinnocenzo, J. P.; Zielinski, P. A.; Farid, S.; Wosinska, Z. M.; Gould, I. R. J. Org. Chem. 2005, 70, 3791-3800. doi:10.1021/jo047813g

60. Freeman, D. B.; Furst, L.; Condie, A. G.; Stephenson, C. R. J. Org. Lett. 2012, 14, 94-97. doi:10.1021/ol202883v

61. Dinnocenzo, J. P.; Banach, T. E. J. Am. Chem. Soc. 1989, 111, 8646-8653. doi:10.1021/ja00205a014

62. Zhang, X.; Yeh, S.-R.; Hong, S.; Freccero, M.; Albini, A.; Falvey, D. E.; Mariano, P. S. J. Am. Chem. Soc. 1994, 116, 4211-4220. doi:10.1021/ja00089a010

63. Wayner, D. D. M.; Dannenberg, J. J.; Griller, D. Chem. Phys. Lett. 1986, 131, 189-191. doi:10.1016/0009-2614(86)80542-5

64. Condie, A. G.; González-Gómez, J. C.; Stephenson, C. R. J. J. Am. Chem. Soc. 2010, 132, 1464-1465. doi:10.1021/ja909145y

65. Rueping, M.; Vila, C.; Koenigs, R. M.; Poscharny, K.; Fabry, D. C. Chem. Commun. 2011, 47, 2360-2362. doi:10.1039/c0cc04539j

66. Kohls, P.; Jadhav, D.; Pandey, G.; Reiser, O. Org. Lett. 2012, 14, 672-675. doi:10.1021/ol202857t

67. Hari, D. P.; König, B. Org. Lett. 2011, 13, 3852-3855. doi:10.1021/ol201376v

68. Pan, Y.; Kee, C. W.; Chen, L.; Tan, C.-H. Green Chem. 2011, 13, 2682-2685. doi:10.1039/c1gc15489c

69. Liu, Q.; Li, Y.-N.; Zhang, H.-H.; Chen, B.; Tung, C.-H.; Wu, L.-Z. Chem.-Eur. J. 2012, 18, 620-627. doi:10.1002/chem.201102299

70. Pan, Y.; Wang, S.; Kee, C. W.; Dubuisson, E.; Yang, Y.; Loh, K. P.; Tan, C.-H. Green Chem. 2011, 13, 3341-3344. doi:10.1039/c1gc15865a

71. Dreyer, D. R.; Jia, H.-P.; Bielawski, C. W. Angew. Chem., Int. Ed. 2010, 49, 6813-6816. doi:10.1002/anie.201002160

72. Jia, H.-P.; Dreyer, D. R.; Bielawski, C. W. Adv. Synth. Catal. 2011, 353, 528-532. doi:10.1002/adsc. 201000748

73. Dreyer, D. R.; Jia, H.-P.; Todd, A. D.; Geng, J.; Bielawski, C. W. Org. Biomol. Chem. 2011, 9, 7292-7295. doi:10.1039/c1ob06102j
74. Todd, A. D.; Bielawski, C. W. Catal. Sci. Technol. 2013, 3, 135-139. doi:10.1039/c2cy20474f

75. To, W.-P.; Tong, G. S.-M.; Lu, W.; Ma, C.; Liu, J.; Chow, A. L.-F.; Che, C.-M. Angew. Chem., Int. Ed. 2012, 51, 2654-2657. doi:10.1002/anie.201108080

76. Xue, Q.; Xie, J.; Jin, H.; Cheng, Y.; Zhu, C. Org. Biomol. Chem. 2013, 11, 1606-1609. doi:10.1039/c3ob27400d

77. Rueping, M.; Koenigs, R. M.; Poscharny, K.; Fabry, D. C.; Leonori, D.; Vila, C. Chem.-Eur. J. 2012, 18, 5170-5174. doi:10.1002/chem.201200050

78. DiRocco, D. A.; Rovis, T. J. Am. Chem. Soc. 2012, 134, 8094-8097. doi:10.1021/ja3030164

79. Zou, Y.-Q.; Lu, L.-Q.; Fu, L.; Chang, N.-J.; Rong, J.; Chen, J.-R.; Xiao, W.-J. Angew. Chem., Int. Ed. 2011, 50, 7171-7175. doi:10.1002/anie.201102306

80. Rueping, M.; Leonori, D.; Poisson, T. Chem. Commun. 2011, 47, 9615-9617. doi:10.1039/c1cc13660g

81. Xie, J.; Xue, Q.; Jin, H.; Li, H.; Cheng, Y.; Zhu, C. Chem. Sci. 2013, 4 , 1281-1286. doi:10.1039/c2sc22131d

82. Wang, Z.-Q.; Hu, M.; Huang, X.-C.; Gong, L.-B.; Xie, Y.-X.; Li, J.-H. J. Org. Chem. 2012, 77, 8705-8711. doi:10.1021/jo301691h

83. Zhu, S.; Rueping, M. Chem. Commun. 2012, 48, 11960-11962. doi:10.1039/c2cc36995h

84. O'Donnell, J. F.; Mann, C. K. J. Electroanal. Chem. 1967, 13, 157-162. doi:10.1016/0022-0728(67)80108-6

85. Dai, C.; Meschini, F.; Narayanam, J. M. R.; Stephenson, C. R. J. J. Org. Chem. 2012, 77, 4425-4431. doi:10.1021/jo300162c

86. Xuan, J.; Cheng, Y.; An, J.; Lu, L.-Q.; Zhang, X.-X.; Xiao, W.-J. Chem. Commun. 2011, 47, 8337-8339. doi:10.1039/c1cc12203g

87. Xuan, J.; Feng, Z.-J.; Duan, S.-W.; Xiao, W.-J. RSC Adv. 2012, 2, 4065-4068. doi:10.1039/c2ra20403g

88. Mathis, C. L.; Gist, B. M.; Frederickson, C. K.; Midkiff, K. M.; Marvin, C. C. Tetrahedron Lett. 2013, 54, 2101-2104. doi:10.1016/j.tetlet.2013.02.031

89. Rueping, M.; Zhu, S.; Koenigs, R. M. Chem. Commun. 2011, 47, 8679-8681. doi:10.1039/c1cc12907d

90. Espelt, L. R.; Wiensch, E. M.; Yoon, T. P. J. Org. Chem. 2013, 78, 4107-4114. doi:10.1021/jo400428m

91. Miyake, Y.; Nakajima, K.; Nishibayashi, Y. J. Am. Chem. Soc. 2012, 134, 3338-3341. doi:10.1021/ja211770y

92. Zhu, S.; Das, A.; Bui, L.; Zhou, H.; Curran, D. P.; Rueping, M. J. Am. Chem. Soc. 2013, 135, 1823-1829. doi:10.1021/ja309580a

93. Miyake, Y.; Nakajima, K.; Nishibayashi, Y. Chem.-Eur. J. 2012, 18, 16473-16477. doi:10.1002/chem.201203066

94. Minakata, S.; Ohshima, Y.; Takemiya, A.; Ryu, I.; Komatsu, M.; Ohshiro, Y. Chem. Lett. 1997, 26, 311-312. doi:10.1246/cl.1997.311

95. Kerr, G. H.; Meth-Cohn, O.; Mullock, E. B.; Suschitzky, H. J. Chem. Soc., Perkin Trans. 1 1974, 1614-1619. doi:10.1039/P19740001614

96. Murahashi, S.; Oda, T.; Sugahara, T.; Masui, Y. J. Org. Chem. 1990, 55, 1744-1749. doi:10.1021/jo00293a014

97. Izumi, T.; Kohei, K.; Murakami, S. J. Heterocycl. Chem. 1993, 30, 1133-1136. doi:10.1002/jhet.5570300453

98. Eberson, L.; Persson, O.; Svensson, J. O. Acta Chem. Scand. 1998, 52, 1293-1300. doi:10.3891/acta.chem.scand.52-1293

99. Lowry, M. S.; Goldsmith, J. I.; Slinker, J. D.; Rohl, R.; Pascal, R. A., Jr.; Malliaras, G. G.; Bernhard, S. Chem. Mater. 2005, 17, 5712-5719. doi:10.1021/cm051312+

100. McNally, A.; Prier, C. K.; MacMillan, D. W. C. Science 2011, 334, 1114-1117. doi:10.1126/science. 1213920 
101.Lee, L. Y. C.; Ci, X.; Giannotti, C.; Whitten, D. G. J. Am. Chem. Soc. 1986, 108, 175-177. doi:10.1021/ja00261a029

102.Cai, S.; Zhao, X.; Wang, X.; Liu, Q.; Li, Z.; Wang, D. Z.

Angew. Chem., Int. Ed. 2012, 51, 8050-8053.

doi:10.1002/anie.201202880

103. Carson, C. A.; Kerr, M. A. Chem. Soc. Rev. 2009, 38, 3051-3060. doi:10.1039/b901245c

104.Yu, M.; Pagenkopf, B. L. Tetrahedron 2005, 61, 321-347.

doi:10.1016/j.tet.2004.10.077

105.Griller, D.; Ingold, K. U. Acc. Chem. Res. 1980, 13, 317-323. doi:10.1021/ar50153a004

106.Li, X.; Grimm, M. L.; Igarashi, K.; Castagnoli, N., Jr.; Tanko, J. M. Chem. Commun. 2007, 2648-2650. doi:10.1039/b702157g

107.Maity, S.; Zheng, N. Angew. Chem., Int. Ed. 2012, 51, 9562-9566. doi:10.1002/anie.201205137

108.Zhu, M.; Zheng, N. Synthesis 2011, 2223-2236.

doi:10.1055/s-0030-1260082

\section{License and Terms}

This is an Open Access article under the terms of the Creative Commons Attribution License

(http://creativecommons.org/licenses/by/2.0), which permits unrestricted use, distribution, and reproduction in any medium, provided the original work is properly cited.

The license is subject to the Beilstein Journal of Organic Chemistry terms and conditions:

(http://www.beilstein-journals.org/bjoc)

The definitive version of this article is the electronic one which can be found at: doi:10.3762/bjoc. 9.234 